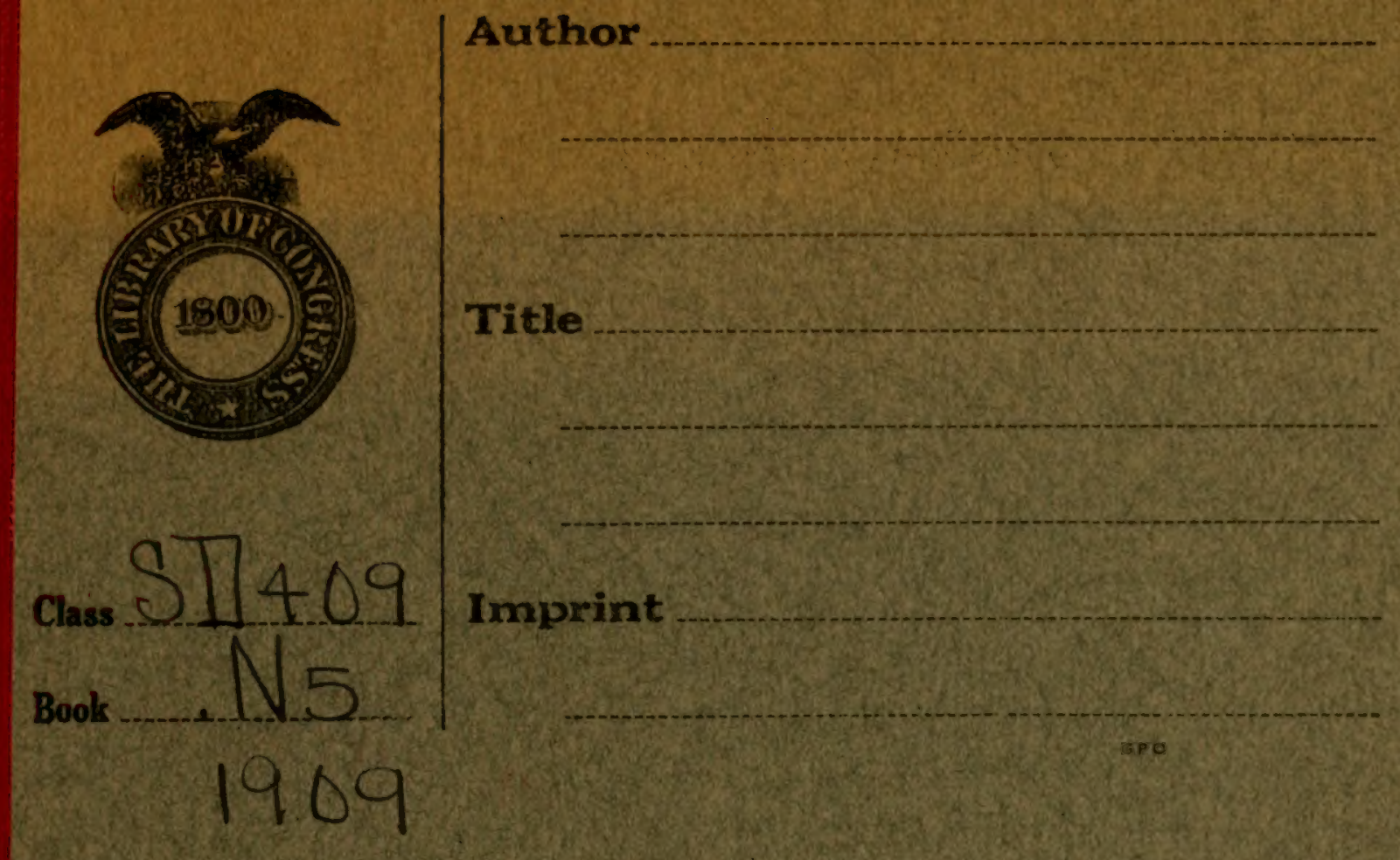



STATE OF NEW YORK-FOREST, FISH AND GAME COMMISSION

\section{Reforesting 0perations}

C. R. PETTIS, State Forester

ExtraCt FROM the FifteEnth ANNUAL Report 

STATE OF NEW YORK-FOREST, FISH AND GAME COMMISSION

\section{Reforesting 0perations}

C. R. PETTIS, State Forester

Extract from the Fifteenth Annual Report

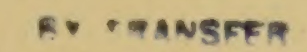

AUG 221918 


\title{
Report on Reforesting Operations.
}

\author{
By C. R. Pettis, State Forester.
}

Hon. James S. Whipple, Forest, Fish and Game Commissioner:

SIR.- The work of this division of the Forestry Department has doubled during the year. We are now operating five large nurseries, reforesting State land, advising private landowners; and have, during the year, supplied large quantities of planting stock to private owners, and carried on experimental work.

\section{TREE DISTRIBUTION.}

This year was the second in which this Commission sold trees to private landowners for reforesting purposes, and the amount sold indicates the demand and the possibilities of reforesting. In I908, seven applicants purchased 25, I00 trees, while in I909, I79 persons bought $1,005,325$ trees and half as many more could have been sold if our supply had permitted. The following tabulation indicates the parties and counties to which trees were sent, also the quantity:

Summary of Distribution by Counties.

Albany County.

F. B. Gilbert................... 4,000

G. C. Leonard.................... 2,000

Dr. H. Van Rensselaer.............. 2,000

John A. Schairer................. $\quad \mathbf{1 , 5 0 0}$

W. L. L. Peltz ................. 3,000

Academy Sacred Heart.............. 2,150

Allegany County. $\quad 14,650$

Frank Sullivan Smith................. 2,000

Broome County.

Binghamton State Hospital. ............... 3,000 
Cattaraugus County.

B. W. Sibley ................. I,

State Nursery ................. 80

I,080

Chautauqua County.

G. R. Butts................... 700

Frank Merz ................... 200

Hon. W. B. Hooker. . . . . . . . . . . . . . 6, 6,000

Hon. A. F. Allen................ 250

Chemung County.

Dr. A. W. Booth................... 3,000

Chenango County.

Lucrus Newton ............... 4,000

Bert Lord ................... I, I,

C. A. Phelps................. 2,000

R. P. Kutschback................ I, I, .

Clinton County.

8,000

J. B. Riley.................. 5, 5,000

G. D. Dare.................. 2,000

W. H. Miner.................... $\quad 4,000$

Columbia County.

I I, OOO

J. V. N. Phillip.

Delazere County.

State Fish Hatchery. . . . . . . . . . . . 6 60,000

R. S. Ives. . . . . . . . . . . . . . 5, 5 ,

John Adams ................. 500

E. E. Brant.................. I,000

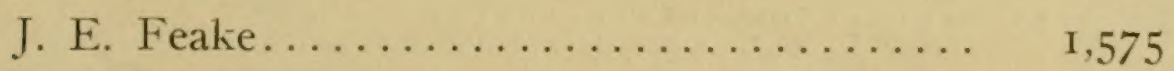

J. C. Wilson. . . . . . . . . . . . . . . 500

J. F. Foreman. .............. 2,000

A. H. Simpson................. 2,000 
J. Q. Barlow.................. I,

A. Yaple ..................... I,000

Thos. Rich . . . . . . . .

John G. Blish................. I, I,

Dutchess County.

P. N. Paine.

1,000

\section{Eric County.}

Julius Goettelman ................ 250

Hon. L. W. Marcus.................. 2,000

Essex County.

Finch, Pruyn \& Co............... I8,000

M. N. Baker................... 6,000

D. G. McGrew ................ I0,000

John B. Burnham. . . . . . . . . . . . . 30,000

Forest, Fish and (xame Commission........ 30,000

I. E. Featherston. . . . . . . . . . $\ldots \ldots$,000

Franklin County.

Thomas Blagden .............. 3,000

Hon. H. H. Hawley ............... 4, 4,000

Joseph Smith ................ I, I,000

Loon Lake Hotel Co................ 2, 2,500

International Paper Co............ 20,000

J. R. Sheffield................ 2,000

Reception Hospital ............... 500

J. O. Ballard.................. 800

Dr. D. H. Dalphin ................ I,

W. D. Warner.................... 200

S. M. Colgate................... I, 600

Fulton County.

C. J. Peters................. 3,500

Warren Miller ................. 20,000 
John Mussey . . . . . . . . . . . . . . . 5,000

Gloversville Water Works............ 20,000

Jeremiah Wood .................. I0,000

C. W. \& J. A. Heacock. . . . . . . . . . 2,000

Holden Lumber Co................. $\quad 2,000$

Z. B. Whitney .............. 1,000

D. A. Hays. . . . . . . . . . . . . . 4,000

Greene Countv.

A. J. Morse................. I,

M. C. Ballard.................. $75^{\circ}$

J. B. Carey................. I,

Hamilton County.

International Paper Co............. I0,000

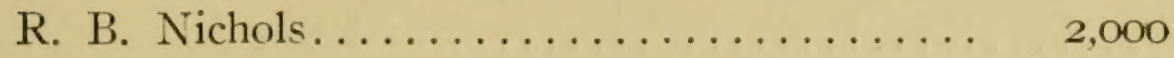

E. H. Johnson . . . . . . . . . . . . . I0,000

John A. Cole. . . . . . . . . . . . . . . . I Io,000

W. E. Brooks ................ I,

33,000

Herkimer County.

C. B. Gray.................. 2,000

M. E. Hastings................. IO IO

D. B. Sperry ................... $\quad 5,000$

Northwood Fishing Club............. I,

J. H. Watson................. I, 1,000

\section{Lezvis County.}

Diana Paper Co................... Io,000

Port Lyden Electric Light \& Power Co..... I, I,O00

J. L. Seymour................. I,000

Hon. Theodore Basselin............ 6,000

Lizingston County.

I 8,000

Bureau of Water, City of Rochester........... 20,000 
Madison County.

D. E. Darrow.

Monroe County.

Hon. H. H. Widener.

Montgomery County.

G. W. Potter

Nassau County.

St. John's Protectory. 900

C. H. Mackay Estate. 65,500

Oneida County.

Hon. Elihu Root................... 31,000

J. S. Baker................... 4,000

John Bliven ................... I,000

J. J. Russell ................... $\quad 2,000$

Q. McAdam ................... $\quad 2,400$

T. W. Parkinson................... 2,000

H. H. Wicks.................. I,000

C. E. Whitcher.................... 500

A. A. Heckert.................. I,000

Dr. C. T. Guillane.................. 2,000

H. J. Cookingham................ 3,000

J. T. Durham..................... 300

A. D. H. Kelsey .................. 500

H. F. Simmons.................... 500

Ontario County.

$5^{1,800}$

J. V. Salisbury \& Son .................... $\quad 3,000$

Orange County.

C. B. Hill................... 3,000

Hon. J. W. Wilkins................. I00 



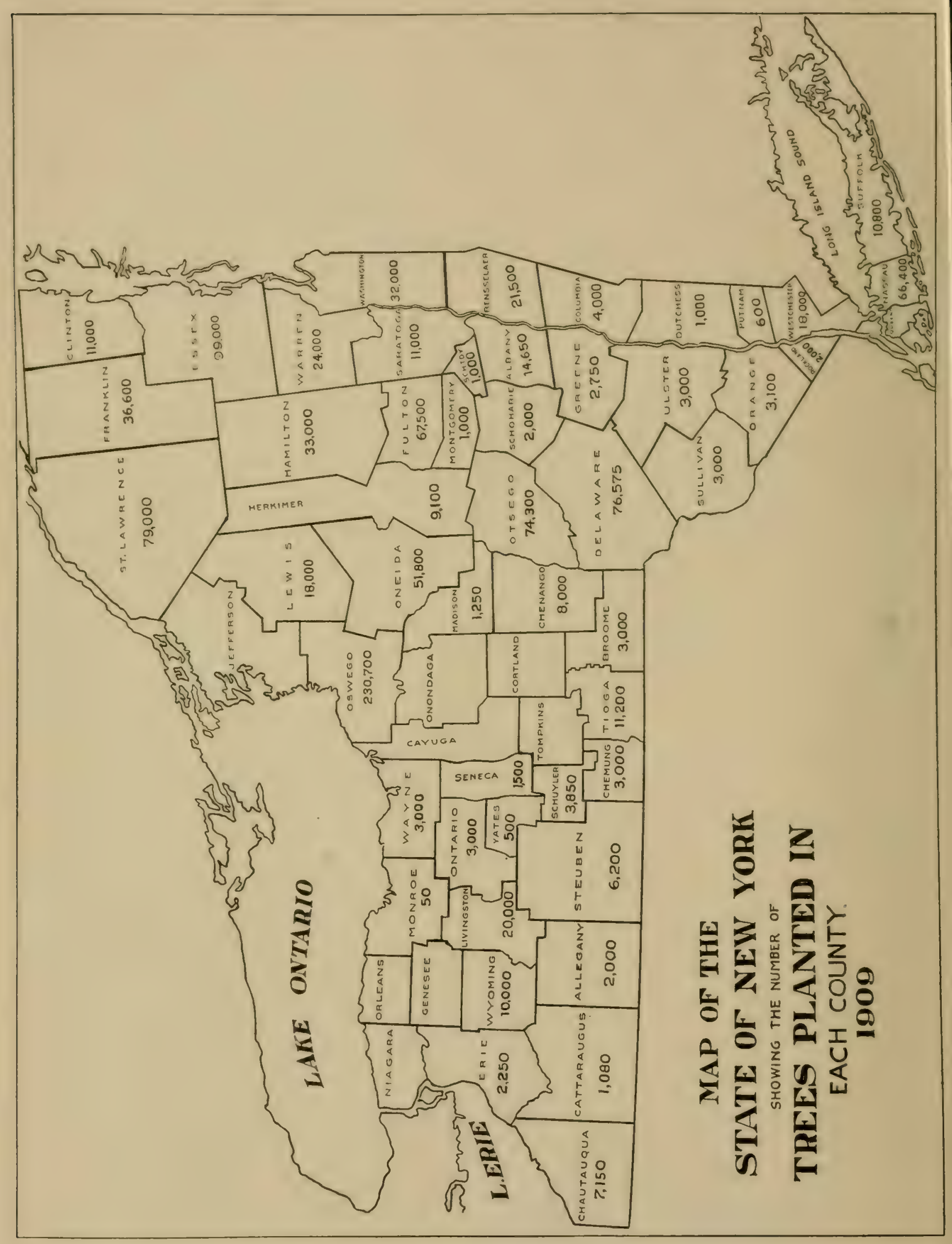


Osicego County.

Great Bear Spring Co........... 209,700

M. N. Wadsworth................ 3.000

Blount Lumber Co................... II,

G. R. \& A. T. Blount............... 7,000

Otsigo County.

W. C. Johnson. .................. 60,000

N. H. Briggs \& Son. . . . . . . . . . . . . 3,000

Ira Mowery .................... I I00

F. E. Golden.................... 200

A. B. Cox........................ I, I,00o

M. E. Baldwin................. 10,000

Putnam County.

Rensselaer County:.

Arthur Cowee ................. I6,500

Robert Olcott .................. 3,500

E. W. Mastin.................... $\quad 1,000$

Dr. H. J. Lipes..................... 500

Rockland County.

H. M. Kennedy 2,000

St. Lanirence County.

F. A. Cutting................. I I , . . .

International Paper Co............ I0,000

Hon. E. A. Merritt, Jr............. 45,000

P. X. Blake.................. 2,000

H. V. B. Ives................. 7,000

Saratoga County.

Union Bag and Paper Co................ II,000 
Schencctady' County.

I. (. Sauter.

1,000

Sihoharic County.

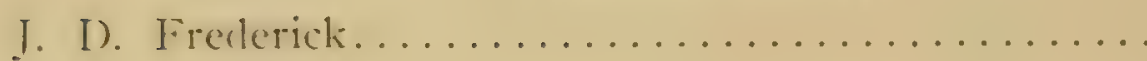

Schuyler County.

Amer. Scenic and Historical Preservation

Society .................. I,450

Hon. W. E. Leffingwell............. 2,400

Seneca Cointy.

Willard State Hospital

Stcubcu County.

J. L. Miller .................. I, 200

J. O. Seabring................ 4,000

Prof. C. K. Robard................ I, I,000

Suffolk County'.

T. H. Bean .................. 3,000

Hon. T. M. Cullen................ 2,000

T. M. Osborne................. I,000

Brooklyn Home for Blind, Crippled and Defective Children ................ 9900

St. Joseph's Convent............... goo

Angustus Eitzen ................ I.000

E. M. \& W. Ferguson............. 2,000

Sullizan County.

C. B. Going...................... 3, 3,000

Tioga County.

A. G. DuBois .................. 7,200

A. W. Booth................. 4, 4,000 


\section{Ulster County.}

Roswell Coles ................... 2, 2,000

13. Frank 1 rood.................. I,000

Harencencounty.

B. G. Higley ................. I, 1,000

D. Hurley .................. . . 3.000

W. H. Faxon................. 5,000

(;. M. Mead.................... 3.000

H. P. King. . . . . . . . . . . . . . 2, 2,000

C. H. Peddrick, Jr............... I0,000

WVashington County.

Spring Brook Water C.o............ \$, \$,

Bossom Mlfg. Co................. 24,000

Waync County.

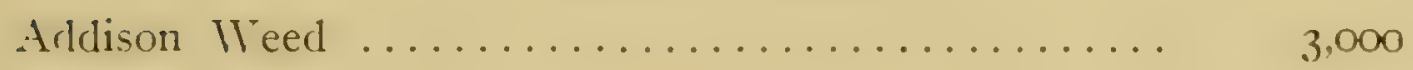

Westchester County.

M. P. Slade..................... I,000

G. Hennig ............... I,000

S. Bonsal .................. 2,000

C. R. Agnew................... 4, 4,000

Capt. John F. O'Ryan.............. 2,000

R. Vander Emde................ 2,000

C. W. Eckhardt.................. 3,000

13. W. Morris.................. 2, 2,000

(\%. I. Mullan................... I.000

18.000

IVyoming County.

Hon. F. C. Stevens.................... 10,000 
Yatcs County'.

Mrs. Edith IV. Lynn ................... 500

Total

$1,095,405$

In order to indicate more clearly what portions of the State are most active in this work, the accompanying map has been prepared.

The following table shows the quantity and species of trees which were shipped during the year to private parties; also the amount planted on State land. 


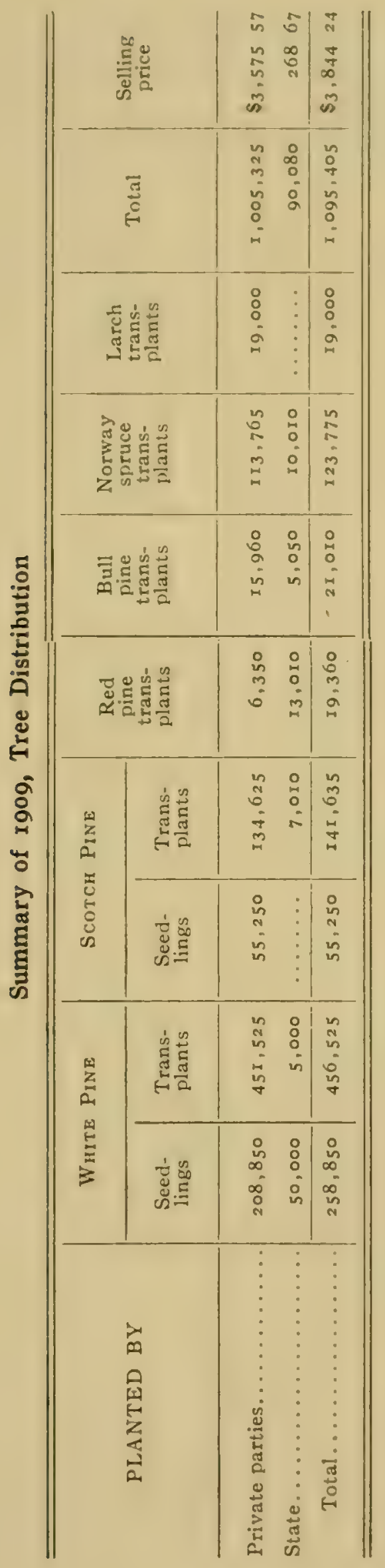


In order to secure reliable information in regard to results of the planting by private land owners, the following blank was sent to each party supplied with trees and a report was asked in accorlance with the agreement they signed when the trees were sold:

$$
\text { .......... N. Y., ... }
$$

Forest, Fish and Game Commission, Albany, X. Y.:

GENTLEMEN.- I make the following report in regard to reforesting with trees purchased from you and planted during the spring of 1909:

Quantity received

Condition of trees when received.

Date of planting.

Number of acres planted.

Cost of planting per acre including trees.

Approximate number living at this time.

Average height growth made this season.

What is your opinion of reforesting?

Have you any suggestions to offer whereby the work can be iacilitaterl?

I) you desire to purchase more trees for next year's planting:

Hout how much reforesting do you intend to do?...........

Do you know of other reforesting in your vicinity and if so, please

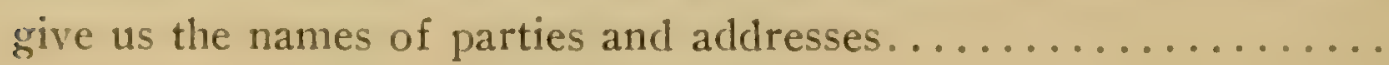

What is your best estimate of the amount of land in your town that (uight to be reforested?

Remarks.

Signed.

P. O

The information received from this source has been tabulated in the following table: 
Forest, Fish and Game Commission.

Summary of 1909 Tree Distribution*

\begin{tabular}{|c|c|c|c|c|c|c|c|}
\hline 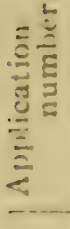 & $\mid \begin{array}{c}\text { COUNTY WHERE } \\
\text { PLANTED }\end{array}$ & $\begin{array}{l}\text { Total } \\
\text { trees } \\
\text { planted }\end{array}$ & $\begin{array}{l}\text { Acres } \\
\text { planted }\end{array}$ & $\begin{array}{l}\text { Per } \\
\text { cent. } \\
\text { livins }\end{array}$ & $\begin{array}{l}\text { Cost ot } \\
\text { llant- } \\
\text { ind ier } \\
\text { acre, in- } \\
\text { clutlins: } \\
\text { troes }\end{array}$ & $\begin{array}{l}\text { Opinion of } \\
\text { reforesting }\end{array}$ & $\begin{array}{l}\text { Estimated } \\
\text { acres of } \\
\text { land in } \\
\text { town that } \\
\text { ought to } \\
\text { be planted }\end{array}$ \\
\hline$x$ & Franklin. & 4,000 & 4 & 90 & St) 50 & Favorable. & 100 \\
\hline $\begin{array}{l}2 \\
3\end{array}$ & 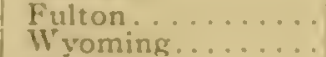 & $\begin{array}{l}20,000 \\
10,000\end{array}$ & 21) & 95 & $\ldots i$ & Hent. & \\
\hline 4 & 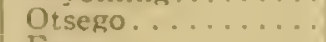 & 100 & & so & . & Favorable. & 1.000 \\
\hline 5 & Essex. & 10,000 & II & 45 & 875 & llent. . & \\
\hline (1) & Fistex. & 10,000 & II & 4) & S 75 & at. . & \\
\hline$\overline{7}$ & Hamilton........ & 2,000 & 2 & yis & 1000 & ellent. & t of town \\
\hline is & $\begin{array}{l}\text { Fulion. } \\
\text { Sullivan }\end{array}$ & $\begin{array}{r}10,000 \\
3,000\end{array}$ & $\begin{array}{l}12 \\
2 !\end{array}$ & $\begin{array}{l}90 \\
90\end{array}$ & $\begin{array}{l}\text { S } 00 \\
\text { is } 00\end{array}$ & $\begin{array}{l}\text { Excellent. } \\
\text { Excollent. }\end{array}$ & $\begin{array}{l}1 \text { of town } \\
25 \text { to } 50 \% \mathrm{c}\end{array}$ \\
\hline 10 & Oassau & 61,500 & $\therefore$ & $i^{2}$ & & & \\
\hline 11 & Mamilion. $\quad \ldots$. & 10,000 & 4 & 95 & 800 & Excellent. & 2.000 \\
\hline 12 & Westchester.... . . & 4,000 & & & $\cdots$ & & $\cdot \cdot$ \\
\hline I3 & Oneida.......... & 1,000 & I & 98 & 1200 & & $\therefore$ \\
\hline$I+$ & $\begin{array}{l}\text { ()sweso. } \\
\text { (1)wero. }\end{array}$ & $\begin{array}{r}3,000 \\
170,700\end{array}$ & $100^{3}$ & 85 & $\begin{array}{r}750 \\
1400\end{array}$ & $\mathrm{E}$ : & $\begin{array}{rl}500 & 25 \\
25\end{array}$ \\
\hline $\begin{array}{l}15 \\
16\end{array}$ & 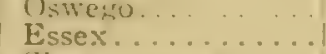 & $\begin{array}{r}170,700 \\
10,000\end{array}$ & $\begin{aligned} 1100 \\
11\end{aligned}$ & 1) 5 & 875 & & \\
\hline I : & Chastaurita. .... & 700 & 1 & 95 & $7 \infty$ & nt. & $10 \%$ \\
\hline Is & Fulion. & 2,000 & 2 & 100 & 1300 & Good.... & $75 \%$ \\
\hline 19 & Westchester..... . & 2,000 & 3 & yo & $\cdots \cdots$ & $\ldots \ldots \ldots$ & \\
\hline 20 & Onejida......... & 4,000 & & 95 & $\therefore 1$ & is & 10,000 \\
\hline 21 & $\begin{array}{l}\text { Cattaraugus...... } \\
\text { St. Lawrence.... }\end{array}$ & $\begin{array}{r}1,000 \\
+5,000\end{array}$ & I & 95 & 700 & lavoralise. & \\
\hline $\begin{array}{l}22 \\
23\end{array}$ & $\begin{array}{l}\text { St. Lawrence..... } \\
\text { Oneida....... }\end{array}$ & $\begin{array}{r}+5,000 \\
1,000\end{array}$ & I & 99 & 1500 & Favorable. & 1.000 \\
\hline 24 & Westchester.... & 2,000 & 2 & 99 & $\ldots \ldots$ & $\mathrm{F}$ & \\
\hline 25 & ()ntario........ & 3,000 & 21 & yo & $1=00$ & t. . & 2.000 \\
\hline 21) & Clinton. & 5,000 & ) & so & 700 & llent.. & 1.000 \\
\hline 27 & Oneila. & 500 & $1 \frac{1}{2}$ & 50 & 1000 & $N$ & $10 \%$ \\
\hline 28 & Albany $\quad \ldots$ & 2,000 & I & 85 & $1+50$ & $N$ & 4.000 \\
\hline 29 & Albany......... & 2,000 & 2 & 95 & 700 & le. & $\cdots$ \\
\hline 30 & kland . . . & 2,000 & $I_{2}^{3}$ & ys & I0 00 & ble. & $\cdot \cdots$ \\
\hline 3 I & $\begin{array}{l}\text { Albany......... } \\
\text { Oneiria. }\end{array}$ & $\begin{array}{l}4,000 \\
2,400\end{array}$ & $\begin{array}{l}10 \\
\cdots\end{array}$ & 98 & 300 & able. & . \\
\hline $\begin{array}{l}32 \\
33\end{array}$ & Otsego.. & 60,000 & 50 & ys & 1080 & Favorable. & $\$ .000$ \\
\hline 34 & Marison & $I, 250$ & 2 & 95 & 750 & Favorable. & 100 \\
\hline 35 & Herkimer. & 100 & . & 90 & $\ldots$ & 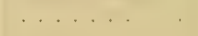 & 2,000 \\
\hline $3^{\prime \prime}$ & Sufiollk. & 1,000 & $\cdots$ & 75 & $\cdots$ & . & $\cdots$ \\
\hline $\begin{array}{l}37 \\
38\end{array}$ & $\begin{array}{l}\text { Herkimert....... } \\
\text { Oneida. . }\end{array}$ & 1.000 & 1 & & & & \\
\hline $\begin{array}{l}30 \\
\text { i9 }\end{array}$ & Otsego.......... & $\begin{array}{l}1,000 \\
3,000\end{array}$ & 41 & $\begin{array}{l}90 \\
98\end{array}$ & $\begin{array}{ll}1 & 00 \\
1 & 00\end{array}$ & . & 100 \\
\hline 40 & Herhimer. & 2.000 & 2 & 98 & 1000 & & $\begin{array}{l}100 \\
500\end{array}$ \\
\hline di & Oneida... & 2.000 & & & & & \\
\hline 42 & Urange & 3.000 & $2 \frac{1}{2}$ & ;0 & & rable. . & \\
\hline 43 & St. Lawrence..... & 2,000 & 2 & 95 & $1: 00$ & Favorable. & 1.000 \\
\hline 44 & Cattaraugust..... & $\cdots \cdots$ & . & $\cdots$ & $\ldots \ldots$ & $\cdots$ & . \\
\hline $\begin{array}{l}+5 \\
+6\end{array}$ & $\begin{array}{l}\text { Franklin } \\
\text { Rocklandt........ }\end{array}$ & $\begin{array}{l}1.000 \\
\ldots\end{array}$ & & & $\begin{array}{l}\ldots \\
\ldots \ldots\end{array}$ & & . \\
\hline 47 & ister... & 2.000 & $I \stackrel{?}{!}$ & 98 & 1500 & N & \\
\hline 48 & Oneitla.......... & 3.000 & 4 & 97 & 1200 & & \\
\hline 49 & Franklin........ & 2.000 & 2 & 98 & $\$ 00$ & Favorable. & $50 \%$ \\
\hline 50 & Greene.... & 1.000 & I & 60 & $\$ 00$ & & \\
\hline 5 I & St. Lawrencet. & $\cdots \cdots$ & i & $\cdots$ & $\cdots$ & & \\
\hline 52 & bany..... & 1.500 & 2 & 90 & ; & & \\
\hline $\begin{array}{l}53 \\
54\end{array}$ & . Lawrence....... & $\begin{array}{l}2.000 \\
\%, 000\end{array}$ & 8 & io & $\begin{array}{r}900 \\
1000\end{array}$ & & \\
\hline 54 & cera. & 1,500 & . & 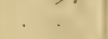 & $\ldots$. & & \\
\hline 56 & stchester... & 3.000 & 3 & ;0 & $\ldots$ & & . \\
\hline 57 & Oiwersts. & 11,000 & 10 & 90 & 1000 & e. . & \\
\hline 58 & Mamilton. & 10.000 & 0 & 90 & 1000 & ahles... & 2.000 \\
\hline 59 & shington.... & 5,000 & 5 & yo & 1000 & Necessity... & 1.000 \\
\hline 110 & $\begin{array}{l}\text { Oranse } \\
\text { Es:ces. }\end{array}$ & $3=, 000$ & 25 & 190 & 1100 &.$\lambda 6$ & \\
\hline $\begin{array}{l}11 \\
62\end{array}$ & taraugus..... & So & & 90 & $\ldots .$. & .16 &., 000 \\
\hline 63 & Montgomery ... . & 1,000 & I & (1)0 & 10.35 & able... & Lat:ace. \\
\hline 64 & Delaware & 2,100 & $1\}$ & , 0 & $i \quad 25$ & Desirable. . & \\
\hline 65 & Scherectady... & 1.000 & & 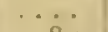 & 1. & & \\
\hline $\begin{array}{l}(1,1) \\
0,-\end{array}$ & Delawire & 2,000 & I & 85 & 1200 & Desirable... & 1.500 \\
\hline 1): & Fulton. & 1,000 & s & 98 & y 00 & & 1.000 \\
\hline
\end{tabular}

* Wherever blanks appear no report had been received when report was prepared.

t Canceled at applicant's request.

+ Cancelled for non-payment. 
Summary of 1909 Tree Distribution *-(Continued).

\begin{tabular}{|c|c|c|c|c|c|c|c|c|}
\hline $\begin{array}{l}0 \\
\vdots \\
\vdots \\
\vdots \\
\vdots\end{array}$ & $\begin{array}{c}\text { COUNTI WHERE } \\
\text { PLANTED }\end{array}$ & $\begin{array}{l}\text { Total } \\
\text { trees } \\
\text { planted }\end{array}$ & $\begin{array}{l}\text { Acres } \\
\text { planted }\end{array}$ & $\begin{array}{l}\text { Per } \\
\text { cent. } \\
\text { living }\end{array}$ & \multicolumn{2}{|c|}{$\begin{array}{l}\text { Cost of } \\
\text { plant- } \\
\text { ing per } \\
\text { acre, in- } \\
\text { cluding } \\
\text { trees }\end{array}$} & \multicolumn{2}{|r|}{$\begin{array}{l}\text { Estimated } \\
\text { acres of } \\
\text { land in } \\
\text { town that } \\
\text { ought to } \\
\text { be planted }\end{array}$} \\
\hline 68 & Oswego........... & 7,000 & 8 & yo & 810 & 00 & Favorable. . I & \\
\hline 69 & St. Lawrence..... . & I 5.000 & . & 95 & & & Necessit $y$. & $\ldots$ \\
\hline 70 & Oswego.......... & 10,000 & ) & 85 & 14 & co & Necessity. & \\
\hline 71 & Hamilton........ & 10,000 & 0 & 95 & 13 & 00 & Favorable. & 10,000 \\
\hline 72 & Franklin......... & 10,000 & 12 & 45 & 15 & ol & Investment. & 16,000 \\
\hline 73 & St. Lawrence.... . . & 10.000 & 1.3 & 10 & 8 & 50 & Necessary... & 5.000 \\
\hline 74 & Franklin.......... & 10,000 & 10 & yo & 14 & 55 & Favorable. . I & 1.000 \\
\hline 75 & Monroe........... & & & So & $\cdots$ & & & \\
\hline 76 & Delaware........ & 1,000 & 3 & (9) & 10 & 50 & Necessary.... & 5.000 \\
\hline 77 & Chenango........ & 1,000 & 1 & ;0 & $s$ & 00 & Necessary... 1 & 4.000 \\
\hline 78 & St. Lawrence.... . . & 10,000 & 10 & 90 & 22 & 50 & Favorable. & 5.000 \\
\hline $\begin{array}{l}79 \\
\text { So }\end{array}$ & Essex . . . . . . . . & 6.000 & 3 & so & 12 & 00 & Desirable... & 500 \\
\hline 81 & Warren........... & 5.000 & 17 & So & 4 & 25 & Necessary... & $10 \%$ \\
\hline 82 & Yates........... & 500 & I & so & 5 & 00 & Desirable... & Much. \\
\hline 83 & Delaware........ & 500 & $\frac{1}{2}$ & 50 & 8 & oo & Favorable. & 5,000 \\
\hline 84 & Greene. & 750 & 2 & 90 & S & 50 & Necessity. & : \\
\hline 85 & Washington...... & 3,000 & & 90 & 10 & 00 & Necessity... & 1,000 \\
\hline 80 & Lewis . . . . . . . . . & 1,000 & $\frac{3}{4}$ & 95 & 12 & $\infty$ & Investment. & $00 \%$ \\
\hline $8 \%$ & 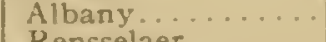 & 3,000 & 3 & 95 & ; & 50 & Favorable.. & 500 \\
\hline 88 & Rensselaer....... & 1.000 & . & $\therefore$ & & & & \\
\hline 89 & Westchester...... & 1.000 & I & 92 & 15 & 00 & & \\
\hline 90 & Fulton ........... & 2,000 & 2 & 95 & 10 & 50 & Favorable & \\
\hline 91 & Oneidat......... & $\cdots \cdots$ & . & 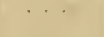 & . & &.$\quad$. & \\
\hline 92 & Saratoga........... & 10,000 & . & & & & & \\
\hline 93 & $\begin{array}{l}\text { Tioga............. } \\
\text { Westchester..... }\end{array}$ & $\begin{array}{l}4,000 \\
2,000\end{array}$ & 2 & & & & Necessit $y^{\circ} . .$. & \\
\hline $\begin{array}{l}94 \\
95\end{array}$ & 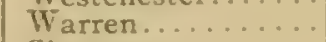 & 3.000 & 3 & 90 & 5 & 75 & Favorable. & 5.000 \\
\hline 96 & Chemung....... & 3,000 & 3 & 90 & & & 20 & \\
\hline 97 & Oneida.......... & 2.000 & $2 \frac{1}{2}$ & 98 & 0 & 75 & Excellent. & MIuch. \\
\hline 98 & Delaware........ & I, 000 & & $\div 0$ & & & Excellent. & 2,000 \\
\hline 99 & Delaware........ & 5.000 & 4 & 85 & i & 00 & Excellent... & \\
\hline 100 & Madison.......... & Refused & & & & & & \\
\hline 101 & Greene.......... . & 1,000 & 3 & 1,0 & 4 & 00 & Protitable. & \\
\hline 102 & Chenango........ & 2,000 & 2 & 80 & 9 & 00 & essity.... & $25 \%$ \\
\hline 103 & Delaware........ & 60,000 & 35 & 85 & ( & & Necessity... & 1.000 \\
\hline 104 & Chautauqua....... & 200 & & 75 & & & Necessity & \\
\hline 105 & 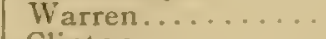 & 2,000 & $1 \stackrel{1}{2}$ & 95 & 10 & 40 & essity.... & 5.000 \\
\hline 106 & Clinton........... & 2,000 & 3 & 80 & 0 & 75 & rable... & 400 \\
\hline 107 & Chenango......... & 4.000 & 6 & So & 5 & 00 & Necessity... & 1.000 \\
\hline 108 & Herkimer. . . . . . . & 5,000 & $3 ! \frac{1}{2}$ & & ro & $\infty 0$ & Favorable. . & 5,000 \\
\hline 109 & Wayne........... & 3,000 & $2 !$ & no & ; & 00 & Favorable. & 300 \\
\hline 110 & Saratoga.......... & $I, 000$ & & 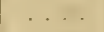 & & & & \\
\hline III & Oneida.......... & 300 & . & 70 & 5 & 00 & Favorable. & 500 \\
\hline 112 & Oneida............ & 31,600 & 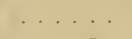 & $\cdots$ & $\cdots$ & . & $\cdots$ & \\
\hline $1 \times 3$ & Dutchess........ & 1.000 & I & 40 & & & & \\
\hline 114 & Clinton ....... & 4,000 & . & . & & $\cdots$ & & \\
\hline 115 & Suffolk..... & 1,000 & . & & . & $\cdots$ & . & $\cdots \cdots$ \\
\hline 116 & Westchester...... & 1,000 & & & & & & \\
\hline 187 & Lewis................ & 1,000 & I & 90 & ; & 50 & Favorable. & Much. \\
\hline I 18 & Oneida .......... & 2,000 & 2 & ys & $\bar{i}$ & 00 & orable. & Miıch. \\
\hline 189 & Oneida....... & 500 & is & 90 & 18 & 00 & Favorable. & I. 500 \\
\hline I 20 & Otsego........ & 200 & $\frac{1}{4}$ & 95 & $\cdots$ & . & Favorable.. & 400 \\
\hline $12 I$ & Livingston and Un- & 20.000 & 9 & & & & & \\
\hline & & 20.000 & 0 & 75 & 15 & 00 & $\begin{array}{c}\text { very Iaror. } \\
\text { able.... }\end{array}$ & \\
\hline I 22 & Rensselaer....... & 3.500 & 3 & & & & & \\
\hline 123 & Steuben.... & $I, 200$ & & & & & & 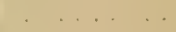 \\
\hline 124 & Steuben... . & 4,000 & & & . & & & $\cdots$ \\
\hline 125 & 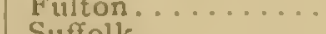 & 5.000 & $4 !$ & 95 & t) & 00 & Investment. & 4.000 \\
\hline 126 & lk & 3,000 & & . & . & & $\mathrm{F}$ & \\
\hline 127 & 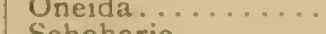 & 500 & 1 & 95 & 10 & 00 & Favorable. & 100 \\
\hline 128 & Schoharie....... & 2,000 & . & . & & $\cdots$ & & $\cdots \cdots$ \\
\hline 129 & Steuben.... & $I, 000$ & I & 95 & & & Necessary. . & 5,000 \\
\hline I 30 & Franklin..... & 500 & $\frac{1}{2}$ & 95 & 14 & & vorable. & \\
\hline 231 & Westchester.... . . & 2,000 & 2 & 75 & 10 & 50 & Necessity... & 5,000 \\
\hline 132 & Westchester. & Canceled & & & & & 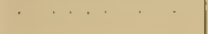 & \\
\hline 133 & 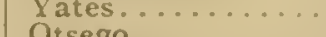 & Canceled & & & & & & $\cdots$ \\
\hline $\begin{array}{l}134 \\
135\end{array}$ & Rensselaer........... & $\begin{array}{r}1,020 \\
10,000\end{array}$ & 1 & 90 & & & & $25 \%$ \\
\hline
\end{tabular}

† Canceled at applicant's req̧uest. 
Forest, Fism axd Game Commission.

Summary of I909 Tree Distribution*- (Concluded(.

\begin{tabular}{|c|c|c|c|c|c|c|c|}
\hline 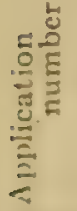 & $\begin{array}{c}\text { COUNTI WHERE } \\
\text { PLANTED }\end{array}$ & $\begin{array}{c}\text { Total } \\
\text { trees } \\
\text { planted }\end{array}$ & $\begin{array}{l}\text { Acres } \\
\text { planted }\end{array}$ & $\begin{array}{c}\text { Per } \\
\text { cent. } \\
\text { living }\end{array}$ & $\begin{array}{l}\text { Cost of } \\
\text { plant- } \\
\text { ing per } \\
\text { acre, in- } \\
\text { cluding } \\
\text { trees }\end{array}$ & $\begin{array}{l}\text { Opinion of } \\
\text { reforesting }\end{array}$ & $\begin{array}{l}\text { Estimated } \\
\text { acres of } \\
\text { land in } \\
\text { town that } \\
\text { ought to } \\
\text { be planted }\end{array}$ \\
\hline 136 & Fulton. & 20,000 & 20 & 99 & 500 & Investment. & \\
\hline 137 & Warren. & 3,000 & 3 & 98 & 900 & Favorable. & 4.000 \\
\hline 138 & Fulton. & 3,500 & 3 & 95 & & Investment. & 7.000 \\
\hline $1 \vdots 0$ & Franklin & 200 & & 50 & & & \\
\hline 140 & Schuyler $\$ . . . . .$. & $\ldots \ldots$ & & & $\ldots \ldots$ & & \\
\hline $1+1$ & Broome........ & 3.000 & $2 k$ & 85 & 650 & Desirable. . & 3,000 \\
\hline $8+2$ & Delaware....... & 1.000 & $\cdots \cdots$ & $\cdots$ & $\cdots \cdots$ & Fis & $\cdots \ldots \ldots$ \\
\hline $\begin{array}{l}1+3 \\
1+4\end{array}$ & $\begin{array}{l}\text { Erie. } \\
\text { Erie. }\end{array}$ & $\begin{array}{r}250 \\
I, 000\end{array}$ & $2^{i}$ & 75 & $\ldots$ & orame & $\ldots$ \\
\hline $1+5$ & Delaware. & $I, 000$ & 1 & 60 & 800 & Desirable... & $33 \%$ \\
\hline 146 & Herkimer...... . & 1,000 & $\ldots \ldots$ & 90 & $\ldots \ldots$ & le... & 4,000 \\
\hline 147 & Delaware........ & I,, 000 & I & $\ldots$ & 600 & e... & 2.000 \\
\hline 148 & 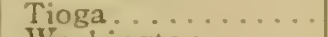 & 7.200 & 5 & 90 & 1200 & ry... & 1,000 \\
\hline$x+9$ & Washington..... & 24,000 & 20 & 98 & 828 & гу.... & $\cdots \cdots$ \\
\hline$\$ 50$ & Franklin........ & 800 & 2 & 90 & 400 & e... & $5 \%$ \\
\hline 151 & Otsego.......... & 10,000 & 8 & 90 & 675 & Hesirable...' & 1.000 \\
\hline 152 & ny........ & 2.000 & $\ldots \ldots$ & ... & ..... & & $\ldots \ldots \ldots$ \\
\hline 853 & Delaware........ & 500 & $\frac{1}{2}$ & 90 & 600 & Nece & 500 \\
\hline $\begin{array}{l}154 \\
155\end{array}$ & $\begin{array}{l}\text { elaer........ } \\
\text { vare....... }\end{array}$ & $\begin{array}{l}6,500 \\
1,000\end{array}$ & $\frac{3}{4}$ & 75 & 500 & агу... & $\cdots 200$ \\
\hline 136 & $\begin{array}{l}\text { Delaware.......... } \\
\text { Delaware...... }\end{array}$ & 575 & $\frac{i}{2}$ & 60 & 800 & ry... & $\ldots \ldots$ \\
\hline 157 & Essex .......... & 18,000 & 15 & 95 & $\ldots \ldots$ & ent. & $\ldots \ldots \ldots$ \\
\hline I 58 & klin....... & I, 000 & $I$ & 90 & 500 & Necessary... & 500 \\
\hline$\$ 59$ & Columbia. . . . . . . & 2.000 & $\ldots \ldots$ & $\cdots$ & $\ldots \ldots$ & $\ldots \ldots \ldots$ & $\ldots \ldots \ldots$ \\
\hline 100 & $N i$ & yoo & & & 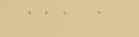 & . & . $\quad$. \\
\hline $\begin{array}{l}161 \\
162\end{array}$ & k. & 900 & $\frac{1}{3}$ & $\begin{array}{l}20 \\
08\end{array}$ & $\therefore$ & Favorable & $\cdots \cdots \cdots$ \\
\hline $\begin{array}{l}162 \\
163\end{array}$ & x..... & $\begin{array}{r}900 \\
5,000\end{array}$ & $4^{5}$ & $\begin{array}{l}90 \\
98\end{array}$ & 800 & orable.. & 3,000 \\
\hline 16.4 & Chenango....... & 1,000 & I & 50 & 700 & Necessary... & 1,000 \\
\hline 165 & Essex......... & 10,000 & II & 90 & 700 & Necessary... & $\ldots \ldots$ \\
\hline 166 & tauqua..... & 6,000 & $\cdots \cdots$ & & $\cdots$ & $\ldots \ldots \ldots \ldots$ & $\ldots \ldots \ldots$ \\
\hline 167 & Hamilton... & I,, 000 & I 1 & 98 & 610 & & 10,000 \\
\hline 108 & Herkimer. & 1.000 & 2 & 95 & & Vecessary. & \\
\hline itig & Schuyler. & 1,200 & . . & & . . & $\cdot \ldots \ldots$ & $\ldots$. \\
\hline 170 & Westchester....... & 1,000 & $\cdots \ldots$ & $\Omega_{n}$ & $\cdots \cdots$ & Vै & $\ldots \ldots \ldots$ \\
\hline $17 \pi$ & ny..... & 2,150 & ${ }^{2} *$ & 80 & $\cdots$ & Necessary"... & $\ldots \ldots$ \\
\hline $\begin{array}{l}172 \\
173\end{array}$ & $\begin{array}{l}\text { Putnam.... } \\
\text { Suffolk.... }\end{array}$ & $\begin{array}{r}600 \\
2,000\end{array}$ & * & $\cdots$ & $\cdots \cdots$ & $\cdots \ldots \ldots$ & $\cdots \cdots$ \\
\hline $\begin{array}{l}173 \\
874\end{array}$ & Ulster. & 1,000 & I & 60 & 650 & Favorable. & 2,000 \\
\hline 175 & Rensselaer. . & 500 & $\ldots \ldots$ & 80 & $\ldots \ldots$ & portant.. & $\ldots \ldots$ \\
\hline 176 & Oswego.......... & 15,000 & I 2 & 85 & I 500 & Important... & $\ldots \ldots \ldots$ \\
\hline 77 & ren.... & 10,000 & I I & 80 & 1000 & Important.. & 5,000 \\
\hline $1-8$ & ent. & 1.000 & & & & & \\
\hline 179 & Lewis .... . & 6,000 & 10 & 90 & 572 & Necessary... & $\ldots \ldots \ldots$ \\
\hline 180 & klin... & 500 & $\frac{1}{2}$ & 90 & 600 & y... & $\ldots \ldots \ldots$ \\
\hline $18 \mathrm{r}$ & on..... & 2,000 & 2 & 90 & 775 & Necessary... & 4,000 \\
\hline 182 & Franklin... & 700 & 6 & 90 & 300 & & $\ldots \ldots \ldots$ \\
\hline 183 & Fulton.... & 2,000 & 2 & 90 & 775 & Necessary... & $\ldots \ldots \ldots$ \\
\hline 184 & Chautauqua.. & 250 & $\ldots \ldots$ & $\cdots$ & $\ldots \ldots$ & $\ldots \ldots \ldots \ldots$ & $\ldots \ldots \ldots$ \\
\hline 185 & Franklin... & Refused & & & & & $\ldots$ \\
\hline $18 \%$ & Erie......... & Refused & $\cdots$ & $\ldots$ & . & $\ldots \ldots \ldots$ & $\ldots$ \\
\hline 10 & Oswego..... & 5,000 & 4 & 95 & 1600 & $\ldots \ldots \ldots \ldots$ & $\ldots \ldots \ldots$ \\
\hline 189 & ego.... & 9,000 & $7 \frac{1}{2}$ & 95 & $16 \simeq 00$ & & $\ldots \ldots \ldots$ \\
\hline
\end{tabular}

* Transplanted in garden for one year.

$\$$ To be shipped in rgro.

This shows that through our efforts $\mathrm{I}, 000$ acres of private land was reforested during the past year. The trees were set at various spacings from as wide as Io $\mathrm{ft}$. by Io $\mathrm{ft}$. to as close as $6 \mathrm{ft}$. by $6 \mathrm{ft}$; and some of the trees were used for underplanting, while a quantity of seedlings were set in nursery rows for planting in 


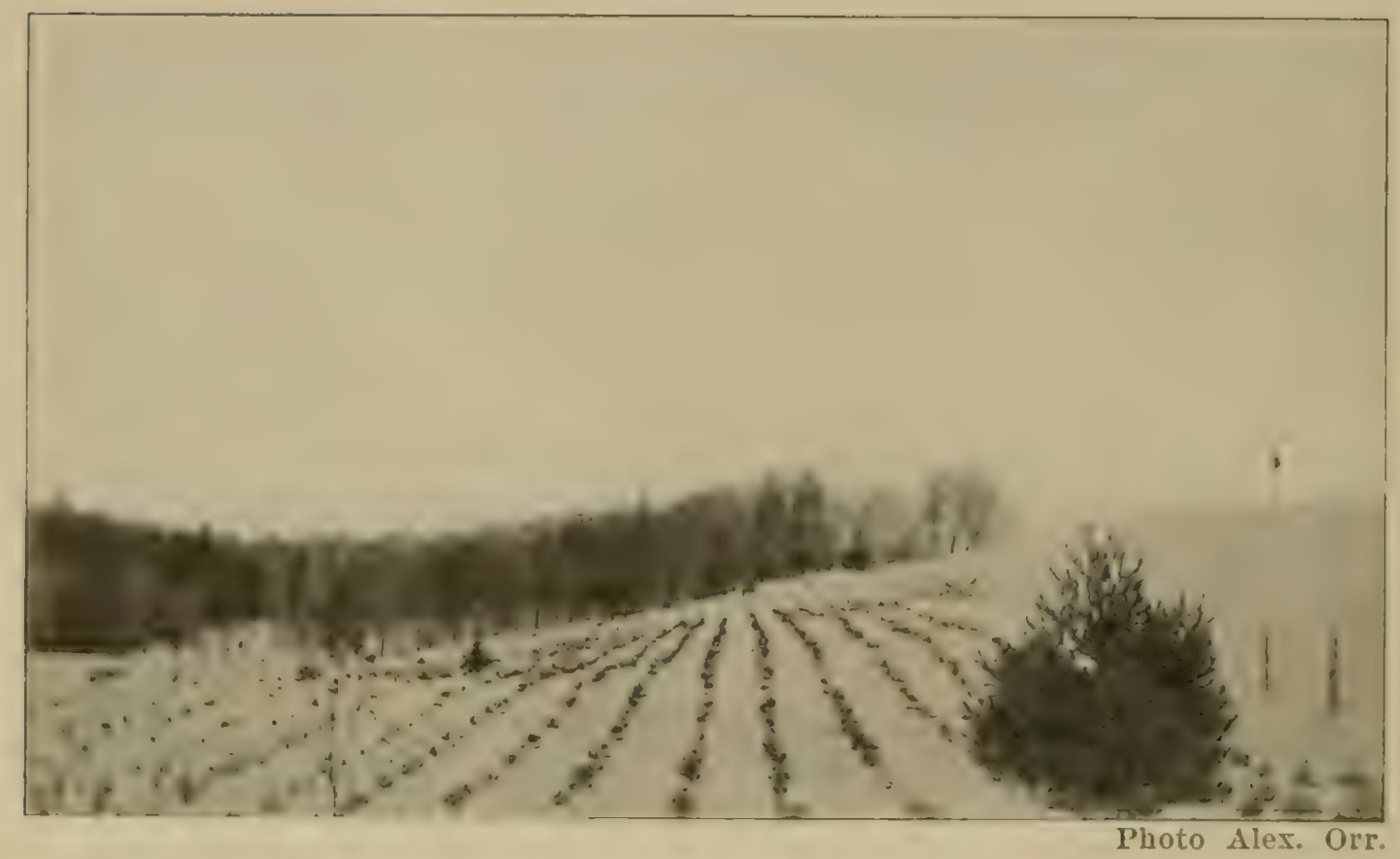

White Pine Plantation of Gloversville Water Works. Photo taken two Years after Planting.

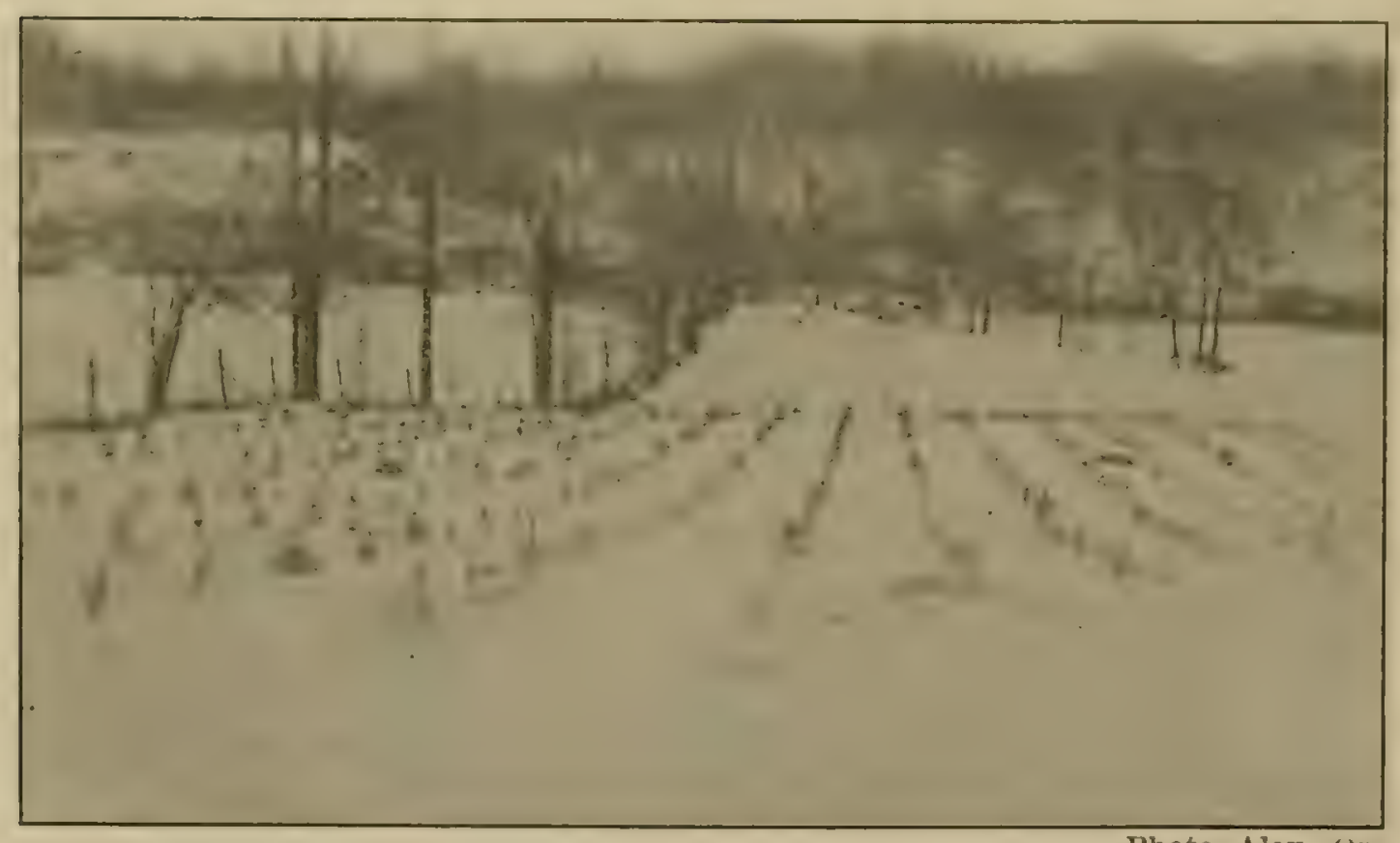

Scotch Pine Plantation of the Gloversville Water Works. 



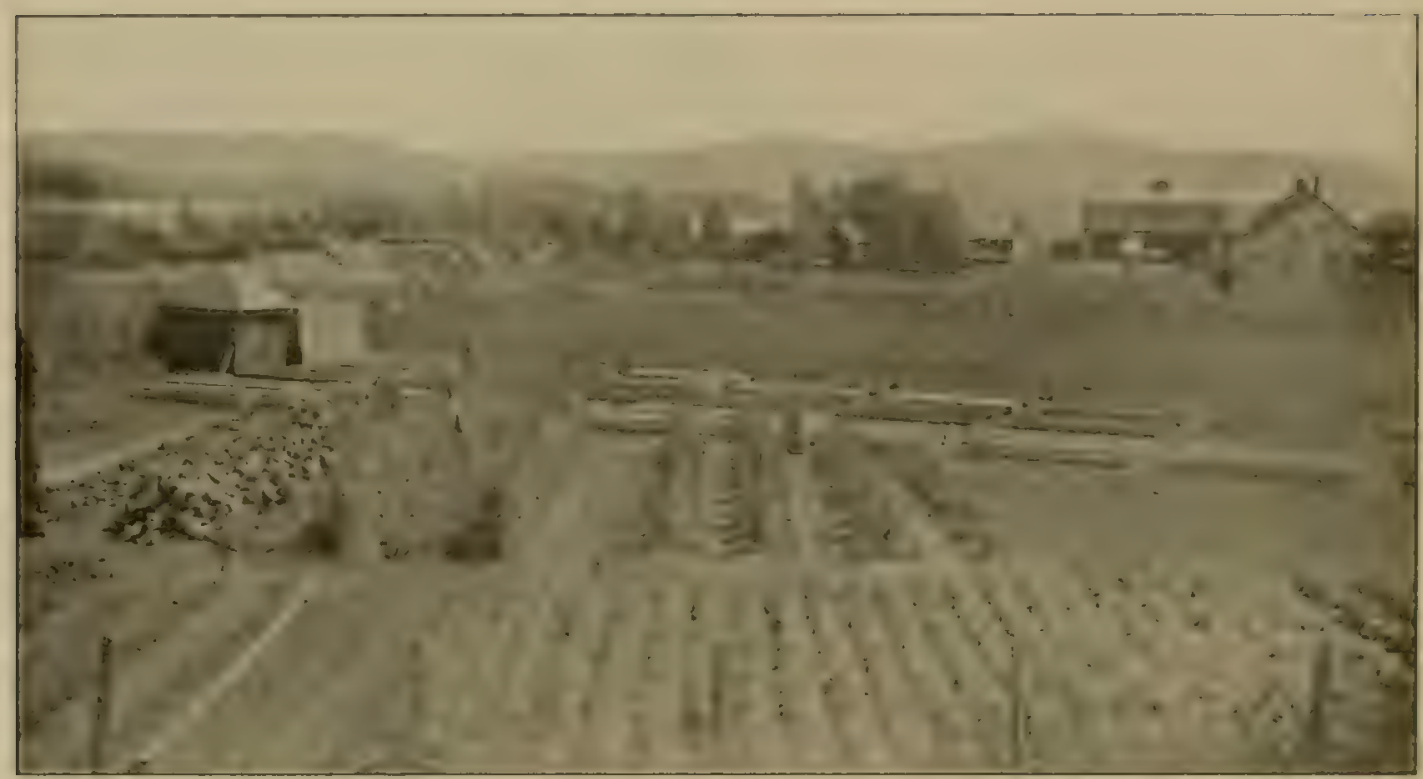

Photo James L. Jacols.

Nursery of Santa Clara Lumber Company at Tupper Lake Junction, N. Y.

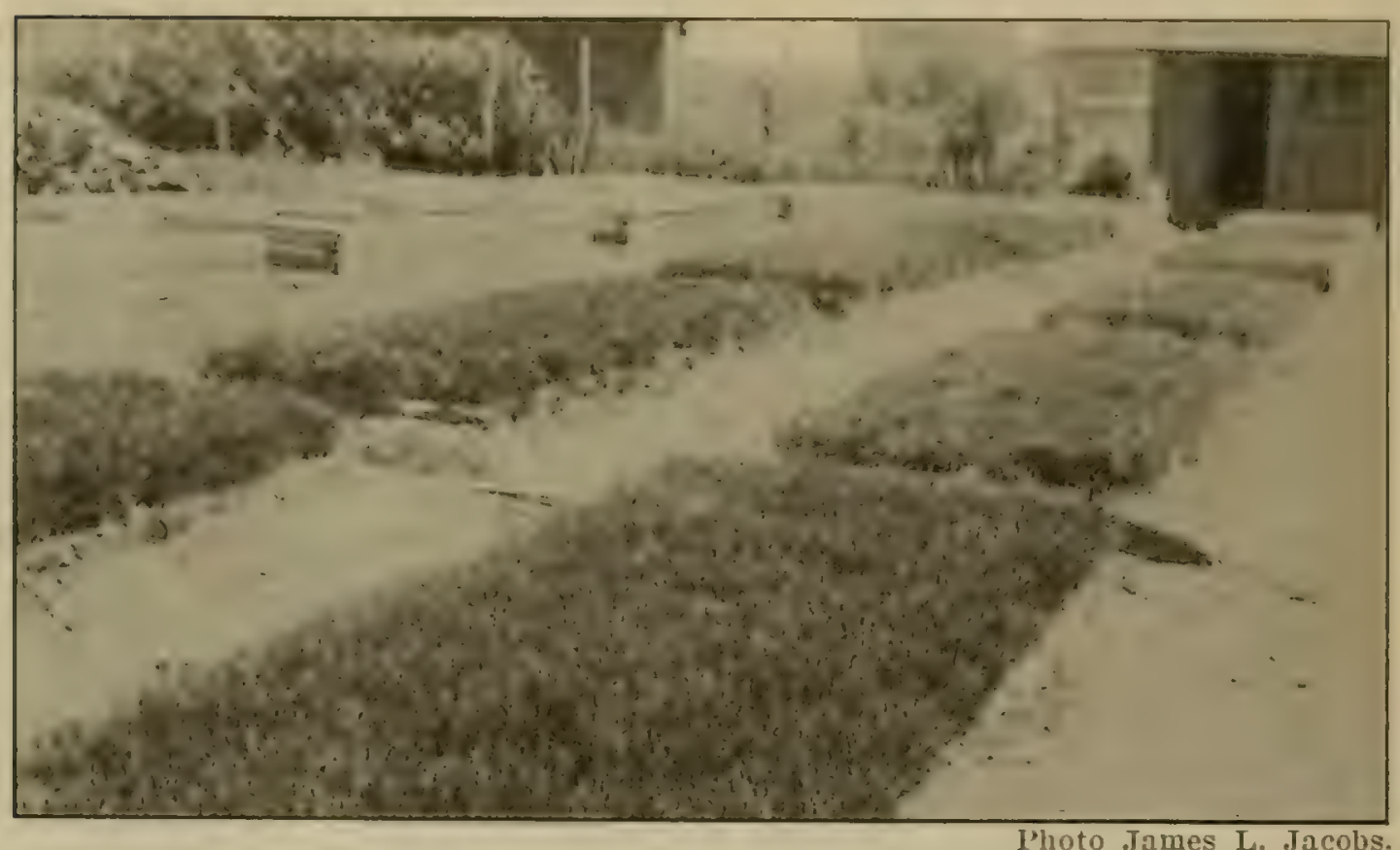

Second Year Seed Beds in Nursery of the Santa Clara Lumber Company at Tupper Lake Junction. 
our nurseries but they are being increased as rapidly as funds permit. However, we cannot supply trees faster than they will grow and it requires a few years for us to bring our nurseries into shape to supply the amount, ages and kinds of planting stock required.

\section{PRIVATE PLANTING.}

Reforesting has been going on in this State several years, but it is difficult to determine how much has been accomplished.

The Santa Clara Lumber Company, of Tupper Lake, was probably the first lumber company to begin on a definite plan. In 1905 they established a small nursery at Tupper Lake Junction, which was very successful from the beginning and has been increased from year to year. The nursery now contains 325,000 transplants, of which 200,000 will be ready for field planting the coming spring. They made their first field plantation last year with stock grown in this nursery. It is a pleasure to note their success and the enthusiasm with which they are doing this work. The accompanying plate shows a general view of this nursery, also a group of seed beds.

The Delaware \& Hudson Co., one of the large landowners in the Adirondacks, established a nursery in I905 at Wolf Pond, which has since been under the supervision of technically trained foresters. This nursery now contains 3,000,000 trees of various ages. They intend to reforest about $\mathrm{I}, 000$ acres of their Adirondack land annually. In addition, a hard wood nursery will be started by this company at Oneonta, where they intend to produce annually 250,000 red oak seedlings, to be used for planting Pennsylvania coal lands. These steps are taken by this company for the practical purpose of producing wood material.

Other private nurseries for reforesting land are operated by the West Point Military Academy at West Point, and Mr. Archibald Rogers, of Hyde Park, Prof. A. M. Hollister and Mr. J. M. Smith also have a nursery at Corinth and have put in a cuantity of seed spots. Mr. Frank A. Cutting, of Boston, who owns several thousand acres of land in St. Lawrence county, began planting his land 
three years ago, but has been sowing seed broalcast for nearly ten years and the results are so satisfactory to him that he will continue both methods.

The bureau of water of the city of Rochester began reforesting land around Hemlock lake in I902, when they planted 5,000 trees, repeating it in 1903. but did not clo any more planting until this year when they set 20,000. The city water board of Gloversville is actively at work reforesting its lands. 'The water boards of Glens Falls; Waterville, and Illion begin the coming spring. The board of water supply of the city of New York, which has charge of the large Ashokan reservoir, has asked our assistance in regard to planting and a site has been selected for a nursery.

Mr. WV. H. Faxon, of Chestertown, probably has some of the finest plantations in the State. One of his plantations, of white pine, made in 1884 now has a fine cut of merchantable material. Until this year, Mr. Faxon made all his plantations with native pines collected in the vicinity, but as the supply was limited, he has not been able to plant as much as he desired. He is now using trees from our nurseries. He is a firm believer in tree planting as an investment and is buying wornout farm land for the sole purpose of planting.

The Great Bear Spring Company, of Fulton, probably planterl more trees than any other party in this State during the year. They lave several hundred acres of land which they are rapidly reforesting as a protection to their valuable springs. In the past few years they have reforested a large area.

As a result of much correspondence and information secured from various sources, we believe that various private owners have in the last few years, exclusive of 1909 , reforested nearly 2,000 acres of land.

\section{\URSERIES.}

Our five nurseries are located as follows: Saranac Nursery and Forest Experiment Station at Saranac Inn Station; Lake Clear and Patnode Nursery near Lake Clear Junction; and Salamancá Nursery at Salamanca. 



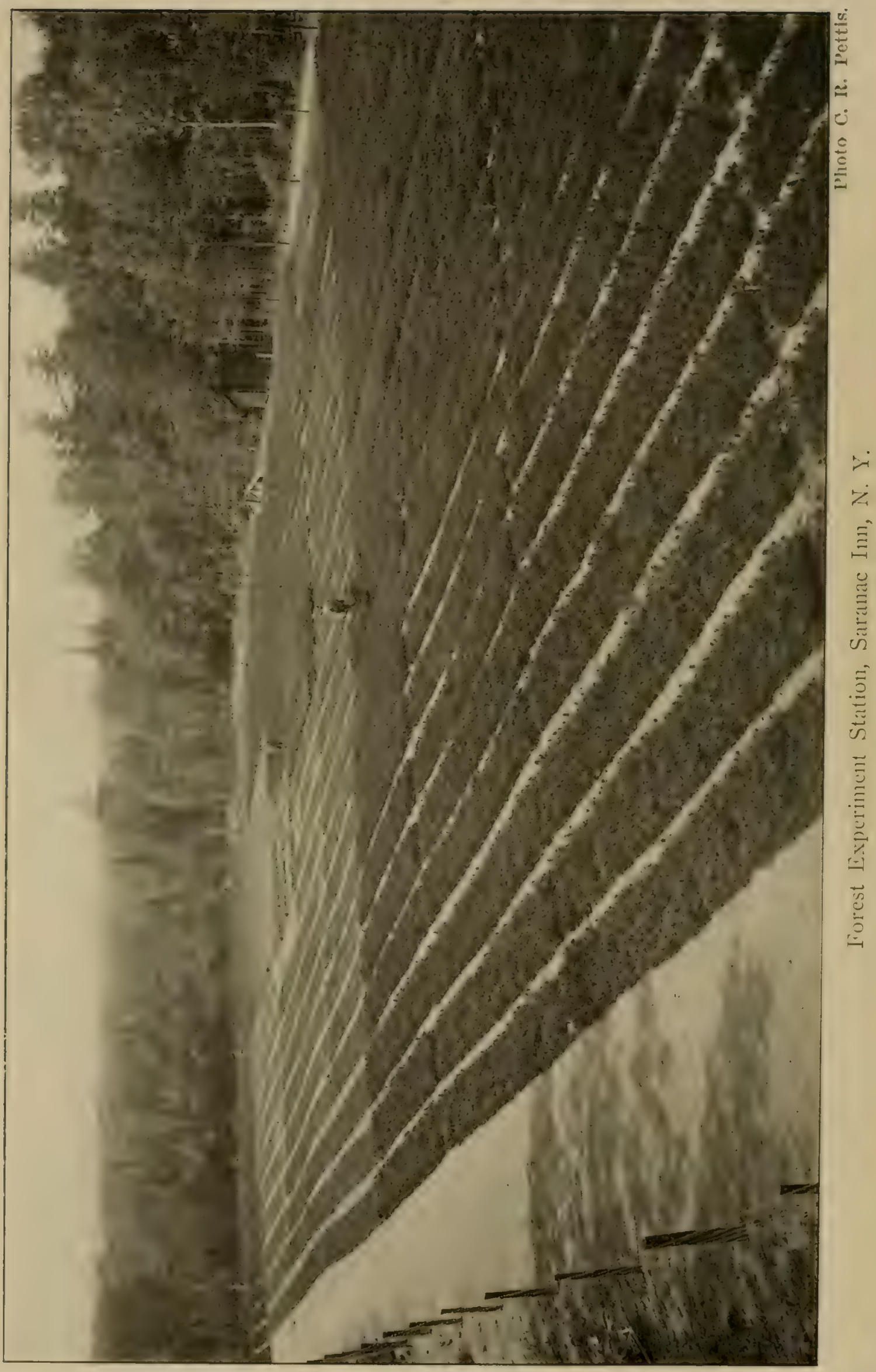


Saranac Nurscry'. The work in this nursery has been conducted the same as in past years. This nursery supplied the following quantities of stock which were sold to private parties last spring:

White pine, 4 year old transplants....... 66,000

Red pine, + year old transplants......... I 3,000

Lull pine, 3 year old transplants......... 18,000

Scotch pine, 3 year old transplants....... 123,000

220.000

The following quantities of seedlings were transplanted in this nursery last spring:

White pine, 2 year old seedlings........ 72,956

Scotch pine, 2 year old seedlings......... 98,995

Bull pine, 2 year old seedlings.......... 48,373

220,324

In addition twenty-four seed berls were sown with seed as follows:

White pine $\ldots \ldots \ldots \ldots \ldots \ldots \ldots \ldots \ldots$

Scotch pine .................. 9

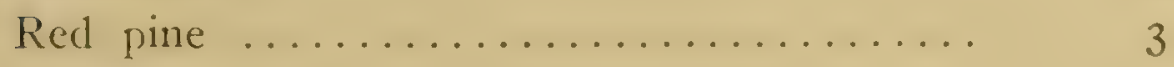

European $\operatorname{larch} \ldots \ldots \ldots \ldots \ldots \ldots \ldots \ldots$

Forest Experiment Station. This nursery has been used both for experimental purposes and as a producer of planting stock. The plan of transplanting one year seedlings has been continued with excellent results. The species used were white, Scotch and red pine. The loss has been very low, not over 2 per cent., and they have made an excellent growth. These Scotch and red pine arc from four to seven inches high, large enough for field planting under certain conditions, while the white pine have made fine roots and when they are three years old will be ideal stock. The disadrantage of this stock is that it is no higher when it is two years old than a seedling of that age and costs nearly twice as much; but it 
is a far better tree to use. On the other hand, if the one year old seedlings are left in the transplant beds two years, they are somewhat more expensive than two year old seedlings, transplanted for one year, but are much beter and are worth more than the difference in price. Photos showing comparative developments of stock uncler these different conditions were published in our annual report for igo8. The three-year transplants (one-year seedlings transplanterl two years) are far more desirable and cheaper than four-year transplants and the former will be generally used in our work where we have been using the latter. Scotch, red and bull pine two-year old transplants (one-year old seedlings transplanted one year) will be generally used in place of the three-year old transplant.

In co-operation with the Bureau of Plant Industry of the United States Department of Agriculture, investigations were conducted to find some remedy for " damping off." We expect after another season to be able to make a final report.

Last September 2,000 Siberian larch, three-year transplants, and 3,000 Japanese larch, three-year transplants, were supplied free to the Great Bear Spring Company, of Oswego, N. Y., under an agreement that they would pay expenses of transportation and planting, hut we were to have the use of all information regarding the adaptalbility and growth of these species.

A series of experiments are now being conducted to test the use of various fertilizers on seedlings and transplants in this nursery.

Excellent results lave been secured by the judicious use of water on our seed beds. It is now too soon to make a full statement in regard to the work.

During the coming year experiments will be conducted with chemical weed killers, hoping by this means to reduce the expense of weeding.

An effort has been made to grow osiers at this nursery. One of the large willow baskets, in which trees were received' from Germany last spring, was torn apart, the rods submerged in water until the buds began to grow, when cuttings were made and set. A large part of these cuttings have made a fine growth. On account 



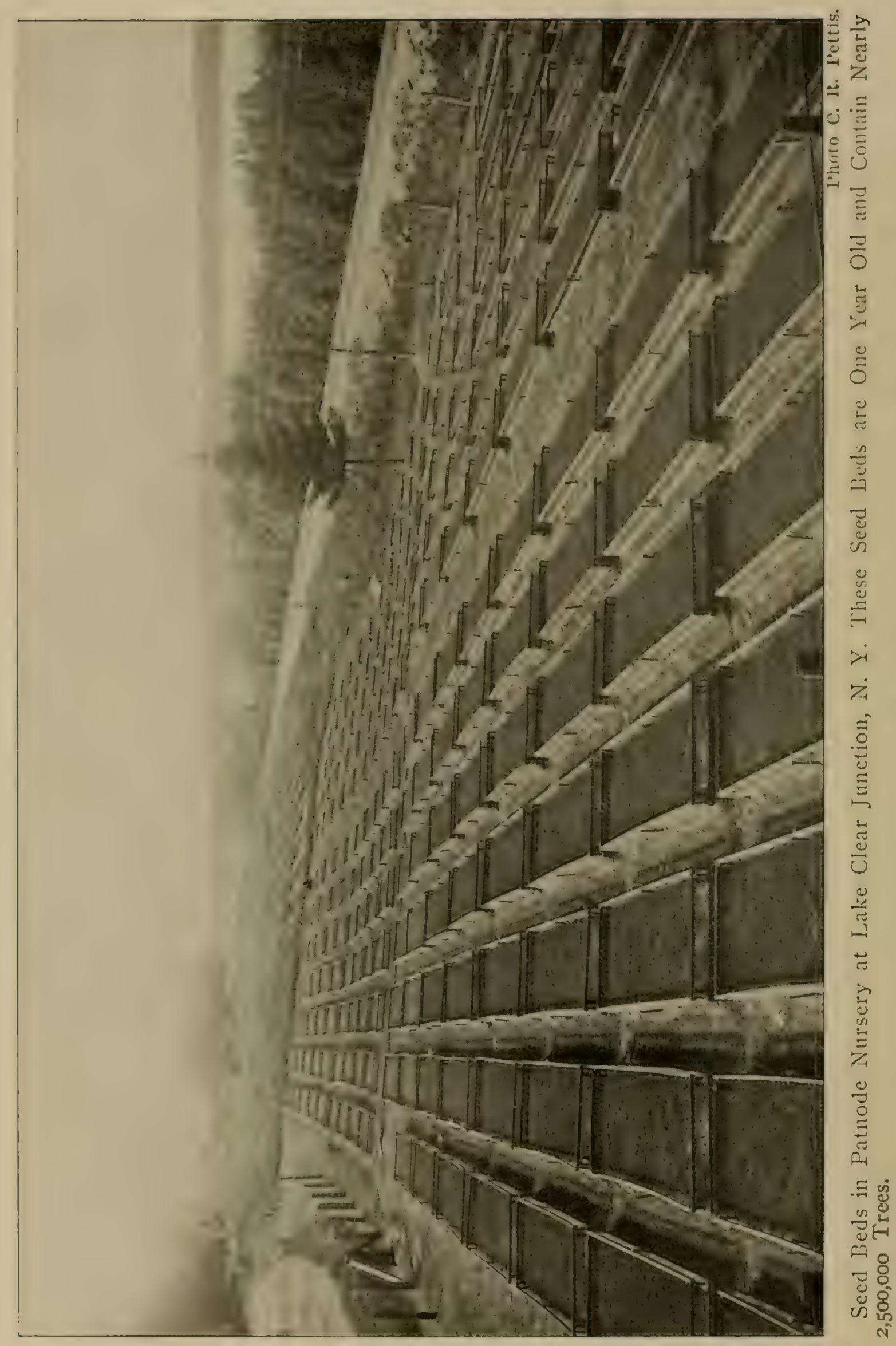





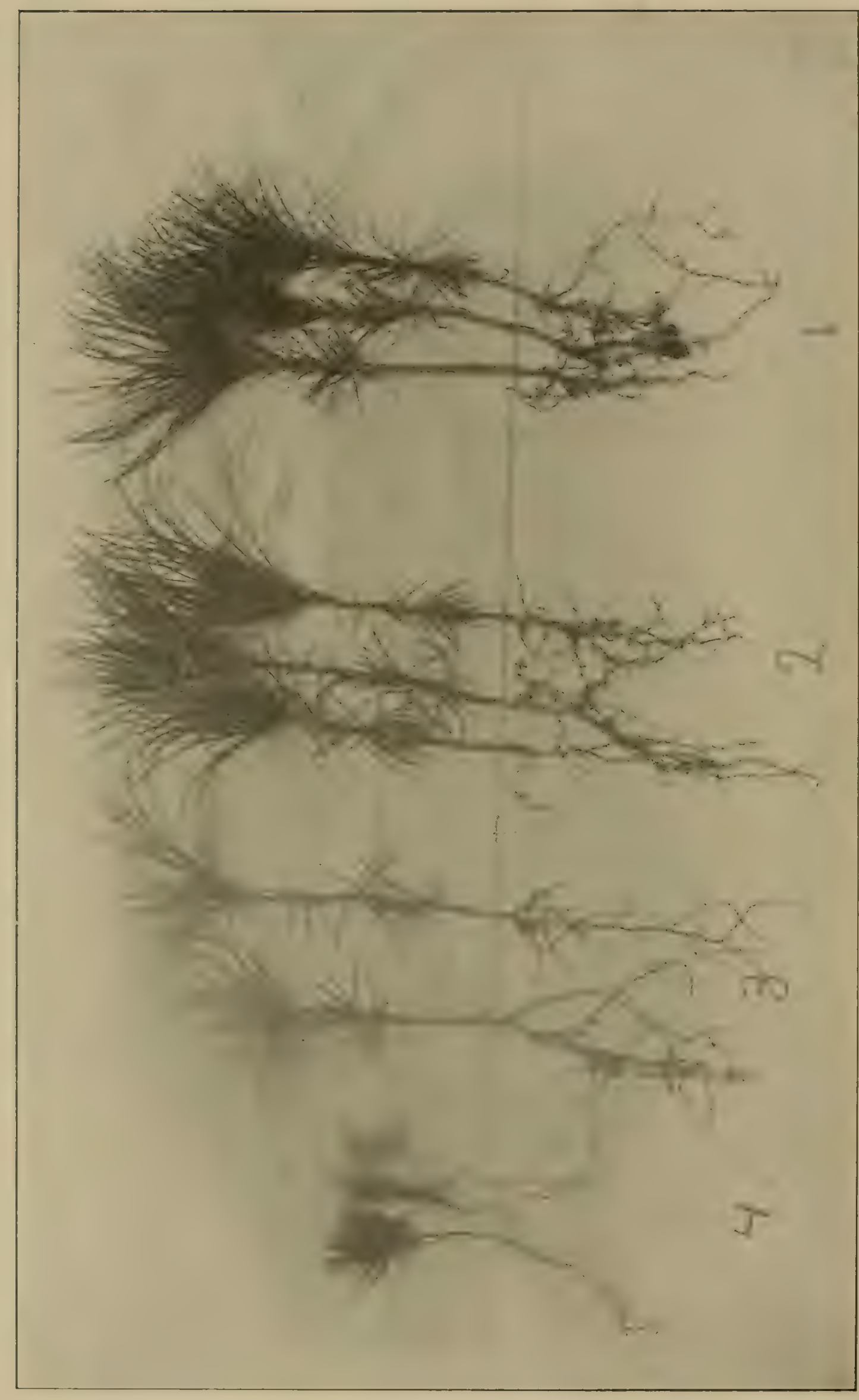

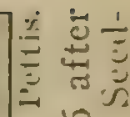

$\therefore$ 客

$\because \equiv$

$m^{\prime}$

暍

岕:

至

\&-

아

$=5$

3

UE

0

$\exists$

证茯

○

$+$

竞

过

is

छ

范

$\cong$

A E

들

3

$\checkmark$

풍

古

政

政

Fi

出

$\because$ ㅎํㄴ

范吉

ह

ن

$\stackrel{\Xi}{\Xi}$

氙

范。

롶

نำ 
of the importance of osier culture in this State the work will be cxtended, but may be transferred to the Salamanca nursery.

This nursery supplied the following quantities of planting material:

Scotch pine, 3-year transplants........ 55,000

White pine, 4-year transplants........ 33,000

Red pine, 3-year transplants......... 5,700

Bull pine, 3-year transplants......... 5,000

Luropean larch, 3-year transplants....... 5, 5,000

Japanese larch, 3-year transplants........ 3,000

Siberian larch, 3 -year transplants........ 2,000

108,700

The following transplanting was clone in this nursery last spring:

Scotch pine, 2-year seedlings........... 2,964

Scotch pine, r-year seedlings........... 23.322

Red pine, I-year seedlings........... I9,006

White pine, I-year seedlings......... 46,6 18

White spruce, 2-year seedlings......... I 3,000

Norway spruce, 2-year seedlings........ I8,395

Siberian spruce, 2-year seedlings........ 2,0I5

Siberian larch, 2-year seedlings......... 2,000

Japanese larch, 2-year seedlings........ 3,000

I 30,320

Six seed beds, four of which were bull pine and two jack pine, were sown.

Lake Clear Nurscry.- This is our largest nursery and will be used as a transplant ground. The following transplanting was done in this nursery last spring:

Scotch pine, 2-year seedlings .......... 255,000

Scotch pine, r-year seedlings .......... 9, 9,000

White pine, 2-year seedlings........... 6r,000

White pine; I-year seedlings.......... 24,000

European larch, 2-year seedlings.......... ro,000

Red spruce, 2-year seedlings........... 7r,000 
This nursery supplied during the year:

White pine transplants............ 78,600

Scotch pine transplants........... 24,000

It now contains 824,000 transplants and 500,000 seedlings.

Owing to the great demand for both seedlings and transplants by private parties we have not had seedlings enough to set all the nursery. This is only the second year this nursery has been in operation, but it will soon have an annual capacity of I,250,000 transplants.

Patnode Nursery. - This nursery was established during the year and is used entirely for the propagation of seedlings. We have in this nursery seed beds as follows:

White pine, I-year old............... I 49

Scotch pine, r-year old................ 60

Red pine, r-year old................ 4

Norway spruce, I-year old............... Io

White spruce, I-year old.............. 2

European larch, I-year old............. 2

These beds except the two containing white spruce are fully stocked and contain not less than 2,000,000 seedlings which have made a fine growth. The accompanying illustration shows the fine condition of the beds.

In order to show the quality of seedlings we are growing and what improvements we have made in this work reference is made to the plate herewith, with the following explanations, all of these plants are two-year old white pine seedlings. Group No. I - trees grown in one of the largest and best commercial nurseries in this country. Group No. 2 - average sized seedlings from our seed beds grown with a much shorter season than No. I. Group No. 4 are the seellings we grew in our nurseries in I903, while Group No. 3 shows the size we grew in $1905-6$, after experiments in soil 



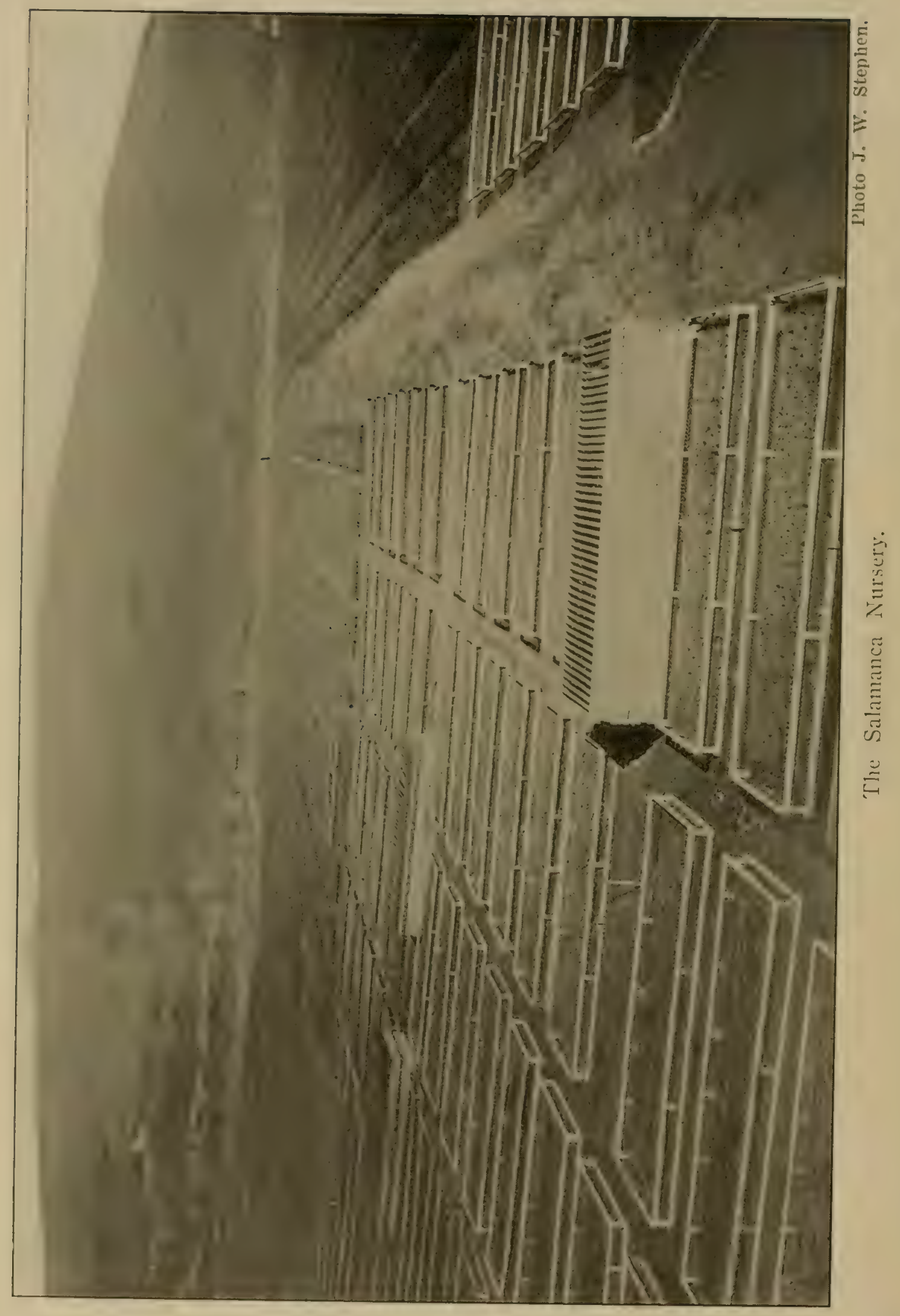


treatment, and Group No. 2 shows what we are growing now after further efforts to improve the quality of seedlings.

Salamanca Nurscry.- The report of work at this nursery, during the year, was prepared by MIr. J. IV. Stephen, resident forester.

The spring of 1909 found us ready for business. Everything of a preparatory nature had been done the fall and summer before.

The winter of Igos-og was very open in this section of the State. Snow fell to a considerable extent at different times, but owing to the repeated thaws it did not remain long on the ground at any time, and was not of great importance as a protection to the trees.

The seed beds were covered with burlap, but in spite of this the repeated freezing and thawing during the winter heaved some of the trees out of the ground. This was especially noticeable around the edges of the beds owing to the fact that the heat from the warm winds and sun affected the soil more readily there than in the interior of the beds. Nore or less of the heat and warm air penetrated under the edges of the frames and thawed this part of the bed while the interior of the bed remained frozen and solid. As soon as the weather would permit, the trees that had been disturbed were replaced in the ground and but few of them were lost. As a whole the trees came through the winter in an excellent condition. To guard against the absence of snow, it will be necessary to take every precaution to protect the seed beds, especially around the edges and prevent the warm air from penetrating under the eciges of the frames. This can be accomplished by allowing the burlap to come well down to the ground on each side and fasten it there by means of dirt or lath. If this precaution is taken very little heaving will occur as the ground, in all parts of the bed, will remain frozen except during a long continued warm spell. If we were sure of an abundant supply of snow and long continued cold weather such precautions would not be necessary.

In the latter part of April, we received two shipments of nursery stock from Germany. These shipments consisted of roo baskets which contained 7or,ooo two-year old white pines and 50,000 one- 
year old Scotch pines. These trees were set out in transplant beds. Each bed was forty feet long and four feet wide, and each was fertilized with about five bushels of thoroughly salted stable manure, which was spaded into and thoroughly mixed with the soil. The trees were planted in rows six inches apart and were spaced four incles apart in the rows, making a little over 1,000 trees to cach bed.

The spring season was cool and wet. Repeated rains occurred during the time of transplanting, hence every condition favorable to the success of the plantation was experienced. The only adverse conclition was from the fact that the rains were too copious, with the result that the ground became so thoroughly saturated, that wherever the beds were made or the planting done with the soil too wet, it afterward became very hard and difficult to cultivate. As a whole, however, the transplanting was very successful, not more than three per cent being lost from failure to grow, although the trees had been out of the ground over four weeks in coming from Germany.

The Scotch pine did not fare so well. The trees, being smaller, were more closely packed and suffered for the want of ventilation. Some of them had moulded and were already dead. Every tree that showed the least indication of life was planted, but we culled out about five thousand, and of the remainder about ten thousand failed to respond at all. The 35,000 remaining have made an excellent growth and are to-day of good size and very thrifty in appearance.

The same can be said of the white pine, so that our transplant beds throughout the nursery are well stocked with a thrifty stand of young trees.

The nursery site for years had been handled as a market garden but with indifferent success. The cultivation had not been thoroughly done and the weeds had been allowed to scatter their seeds. In addition to this more or less weed seed was contained in the manure used for fertilizing, with the result that the warm weather, that followed the abundant rainfall of the spring, brought into being 


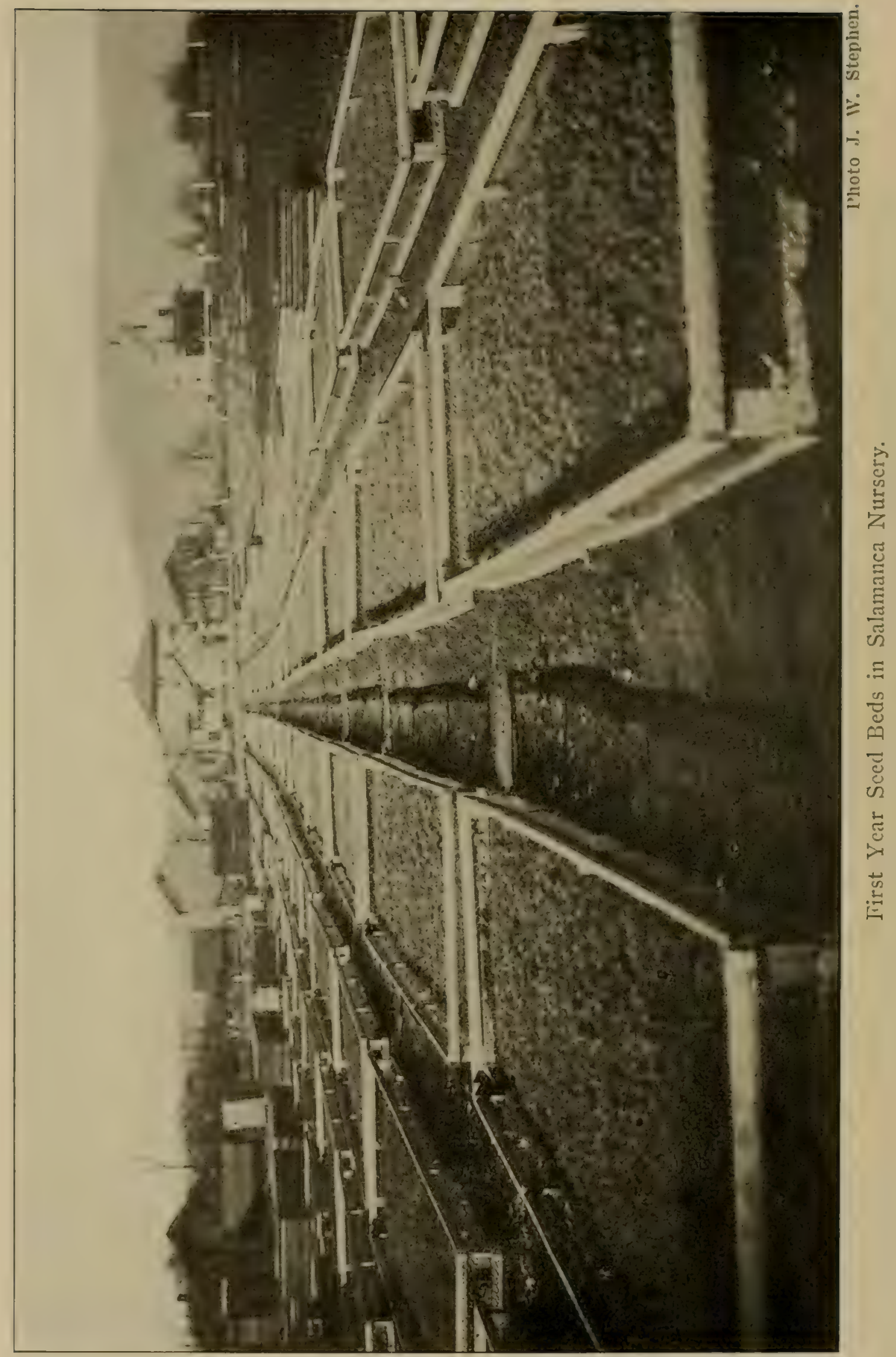


millions of weeds. In order to cope with this condition, it became necessary to employ additional help to clean out the beds and prevent the weeds from seeding again. This we did and we feel confident that in succeeding years the ground can be kept in a desirable condition with much less trouble and expense.

We had considerable trouble from the depredations of a larva, or grub (probably Laclinostccna fusca), of the "June bug," that was very persistent in destroying the trees. This it did by gnawing the bark from the roots and stem beneath the surface of the soil. The only remedy we used with success was to discover the invader and destroy it. This is not so easily done in many cases as the grub had often gone to another locality, when the condition of the tree betrays the fact of its injury. We hesitated to dig up the beds extensively, because the loosening of the trees at this season of the year is harmful to them and often results in their death, so that in order to avoid this as much as possible, we marked the place and visited again in a day or two when we would usually find some new evidence of his presence and could locate him with little trouble. The work of this grub continued throughout the season until toward fall, when it ceased its depredations and went into another stage of its life history. We succeeded in killing hundreds of them and the total number would probably reach well above a thousand. The number of trees killed by them during the summer was approximately two per cent, so that from all causes we lost not far from five per cent of all trees transplanted.

In addition to the transplants we sowed 250 seed beds. They consisted of 155 beds of white pine, 80 beds of Scotch pine, Io beds of Norway spruce, and 5 beds of European larch. The seed beds were made 4 feet by 12 feet, and in this space we sowed broadcast 12 ounces of white pine, 8 ounces of Scotch pine, 8 ounces of Norway spruce, or I pound of European larch, accordto the species of tree we wished to obtain. Each of these seed beds was fertilized with five or six bushels of thoroughly rotted manure and worked deep enough into the soil so that it would not come in contact with the seeds themselves, but would be available 
when the roots of the seedlings reached sufficient depth. The germination of most of the seeds was excellent. The only exception to this was in the case of the European larch which is of rather low germinating power and which came up thin and scattering.

As we lacked sufficient lath to cover some of the beds cluring the period of germination, I made use of the burlaps that were used for winter protection to cover the tops of fifty of the beds. These beds, although they were the last to be sown, were the first to germinate and were fully two days ahead of the same species when covered with the usual lath covering. I believe these burlaps serve to keep the beds warmer and are more economical, in time and expense of placing and removing, than the use of a loose lath covering. Their use would remove the necessity for keeping on hand a considerable quantity of loose lath at all times.

We were troubled somewhat with the "Damping off" disease in our seed beds. This was especially true in the Scotch pine beds and to a lesser extent in the Norway spruce beds. The white pine and larch seemed to be affected very little. We kept the disease in check by a liberal use of washed sulphur. This treatment stopped the ravages of the disease and we have 250 beds that are very uniform in appearance and contain a large number of young ceedlings. The white grub was also troublesome in these seed beds but we lost no opportunity in seeking them out as soon as we detected their presence so that very little clamage resulted from this cause.

In addition to the coniferous seed beds, we sowed eight pounds of black locust, ten pounds of yellow poplar, and ten pounds of white ash seed.

The hardwood seeds were planted in drills sixteen inches apart so that they could be cultivated with hand cultivators. The results are quite satisfactory.

The locust germinated readily and made an excellent growth, some of them reached a height of four feet during the season.

The yellow poplar was late in coming up. It clid not germinate 



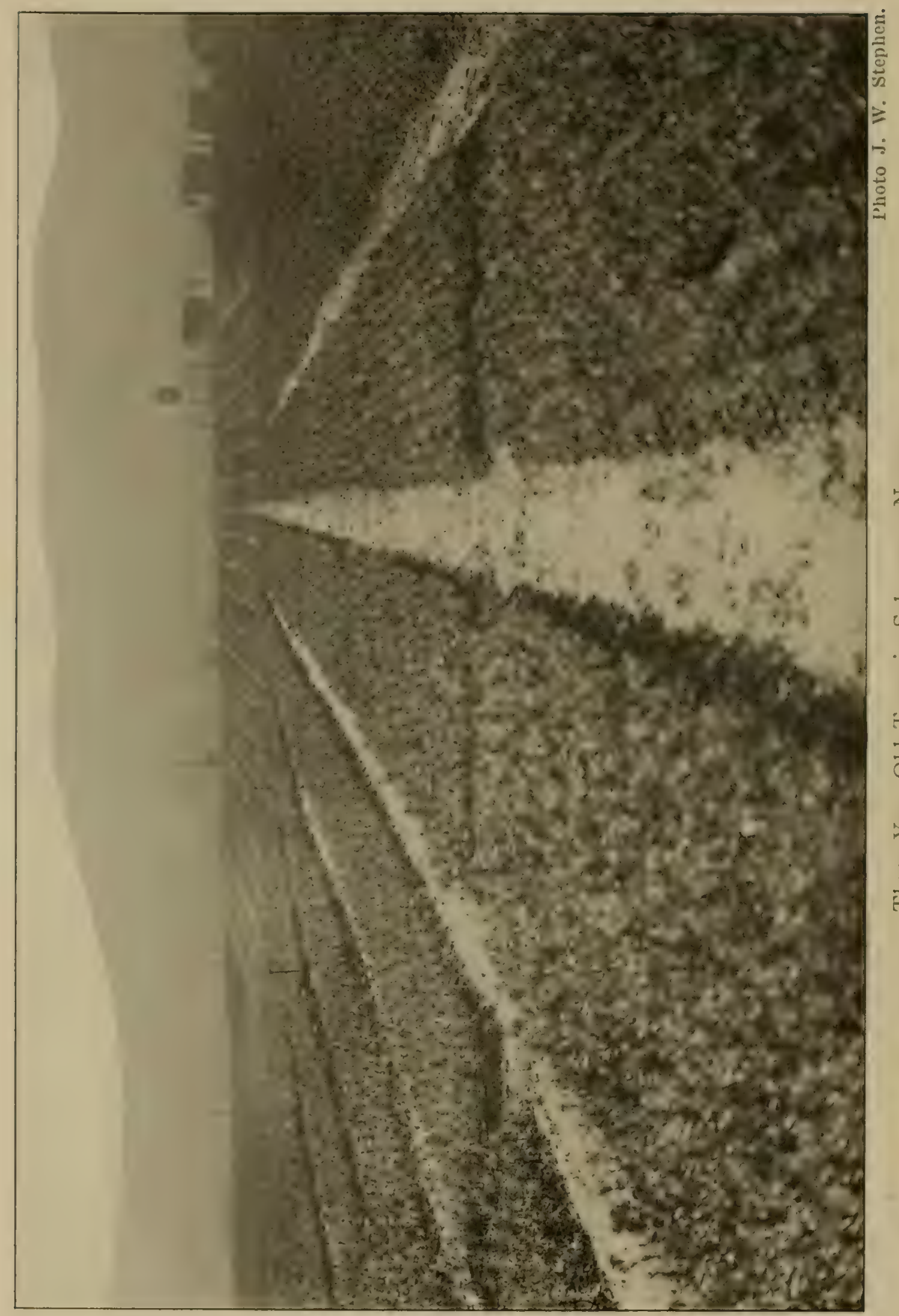


until the last of June and the growth was slow. The best of them are now only about six inches tall. The seed of the yellow poplar is of very low germinating power, about five to ten per cent germinate as a rule. For this reason it is necessary to sow the seed very thickly in order to secure a satisfactory stand. If this valuable species is to be propagated extensively, it will be necessary to sow a large quantity of the seed. Although these seeds were slow in germinating, we obtained a fair number of trees and some visitors, who have had considerable experience raising them, thought we obtained very good results.

The white ash was a complete failure; none of the seeds germinated although they may do so the coming spring after lying in llie ground throughout the entire season. All of these seeds were thoroughly soaked for several days before sowing and should have been in good condition for germination.

The copious spring rains were followed by a long season of dry weather and it became necessary to rely on our water plant for irrigation purposes. Our water pressure was sufficient to sprinkle all parts of the nursery and throughout the season we had an abundant supply of water. This was very gratifying as there had been some question as to whether our well would furnish an adequate supply, throughout the entire summer, in case there was an cxtended drouth. The results were entirely satisfactory, removing ali cloubts for the future.

During the early spring we increased the area of the nursery by the purchase of an adjoining plat of ground containing five and three-tenths acres. This doubled the area of our nursery, making the total area approximately ten and one-half acres. This land adjoins our original purchase on the east and extends from Broad to Carydon streets, on both of which we have a frontage of fifty fect for an outlet. During the summer we have enclosed this new area with a good fence and endeavored to bring the land into as favorable condition as possible for our purpose. In order to enrich this soil it was covered with stable manure and plowed under. It was then sowed with peas and they in turn, at maturity; were 
jiowed under. Another coat of manure was then applied and by repeated cultivation has been thoroughly incorporated with the soil. A large portion of the weed seed has germinated and been destroyed, so that we expect, when this area is finally planted as a nursery, we will avoid much of the trouble and expense of getting rid of the weeds.

With this addition to our nursery, all under cultivation, it will give us a capacity of practically $\mathrm{I}, 000,000$ four-year old transplants per year, and an equal number of two-year old seedlings of coniferous species. If a part of the nursery is permanently used for the propagation of hardwoods, this will decrease the number of conifers that will be available each year.

At the present time, with less than half of the land occupied, we have the following stock in the nursery:

670,003 three-year old white pine transplants,

35,000 two-year old Scotch pine transplants, 400,000 two-year old white pine seedlings,

1,750,050 one-year old white pine seedlings,

650,000 one-year old Scotch pine seedlings, I00,000 one-year old Norway spruce seedlings, 25,000 one-year old European larch seedlings, 23,000 one-year old black locust seedlings, 2,000 one-year old yellow poplar seedlings.

THE EUROPEAN BLISTER RUST.

In order to supply the demand for planting stock for reforesting at a reasonable price it has been customary to import small trees from Germany and France. This State and several other states in the northeast, imported large quantities last spring. After the trees had been unpacked and the annual growth began, one of our experienced men, who was superintending a large planting operation, noticed some peculiar coloring of the body of some of the little trees. He immediately referred the matter to the writer, who suspected the trouble might be this rust and promptly took steps to secure specimens. Some affected trees were secured from 



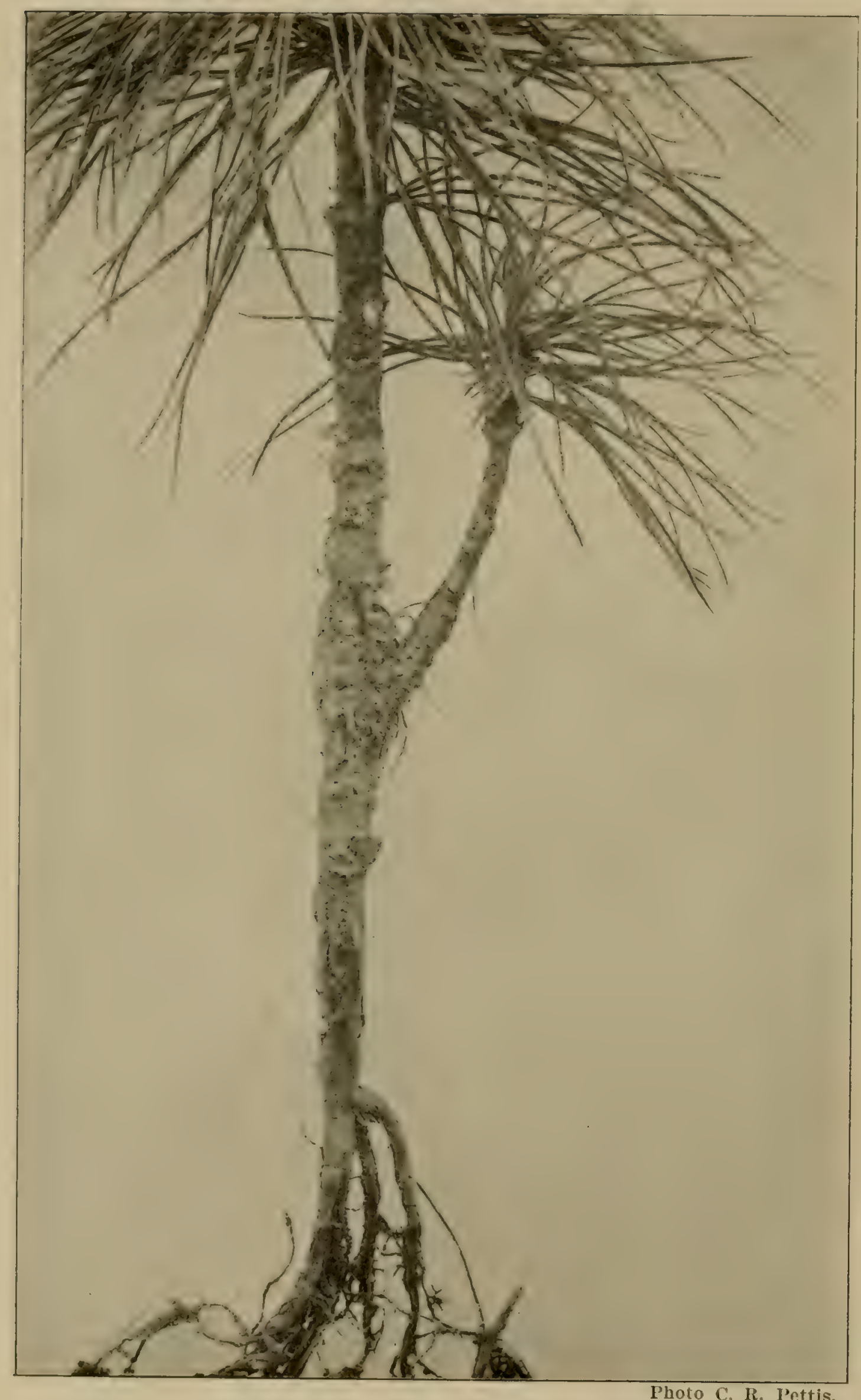

White Pine Transplant Affected with the German Blister Rust. The CupLike Projections on the stem are the Spore Bodies. 
this plantation and an examination of some plants of the same age and from the same German nursery, which had been set in our nursery at Lake Clear, showed the same disease. Dr. Spaulding of the $U$. S. Bureau of Plant Industry was present and confirmed the identification as Pcridcrmium strobi, Klebahn, commonly called the white pine blister rust.

The fact that this disease had been found was at once communicated to Commissioner Whipple, who immediately called a conference to meet in New York city, Jume 28th, inviting all the State and large private forestry interests from Maine to Maryland and west to Ohio. The following is a copy of the letter calling the conference:

$$
\text { "SALAMANCA, N. Y., Junc 22, 1909. }
$$

"DEAR SIR.- Owing to the fact that there has been discovered on white pine planting stock, recently imported from Germany into at least three of our States, a serious fungus disease - the European currant rust - which endangers all white pine in this country, I take the liberty to ask your careful consideration of this important matter.

"The disease seriously affects the growth of white pine, and eventually kills the affected trees. It has become so serious in some countries, notably Holland, as to prohibit the use of this, our most valuable tree. I believe if prompt action is taken this serious disease can be stamped out. If action is not taken immediately I believe that the future use of white pine must be abandoned.

"On account of the gravity of the situation I am taking the liberty of calling a conference of the forestry interests of the Northeastern states at the office of this Commission, No. I Madison Avenue, New York City, Monday, June 28, at I P. M.

"You are urgently requested to be present and to wire your acceptance to me at Salamanca, N. Y., on receipt of this letter.

"Very sincerely yours,

$$
\text { "(signed) J. S. WHIPPLE, }
$$

"Commissioner". 


\section{Minutes of Conferencl: of State Foresters}

held at the office of the New York Forest. Fish and Game Commission, No. I Madison avenue, New York city, June 28, Igog, to consider the matter of a disease affecting white pine known as "European Currant Rust" or "Blister Rust," imported from Germany.

Hox. JANES S. WHIPPLE, Chairman.

Present :

Mr. IV. O. Filley, Acting State Forester, New Haven, Conn.

Mr. A. F. Hawes, State Forester, Burlington, Vt.

Mr. Alfred Gaskill, State Forester, Trenton, N. J.

Mr. F. IV. Rane, State Forester, Boston, Mass.

Mr. C. R. Pettis, State Forester, Albany, N. Y.

Dr. Perley Spaulding, Bureau of Plant Industry, Washington, D. C.

Dr. Haven Metcalf, Bureau of Plant Industry, Washington, D. C.

Mr. Raphael Zon, Forest Service, Washington, D. C.

Hon. R. A. Pearson, Commissioner of Agriculture, Albany, N. Y.

Hon. J. S. Whipple, Forest, Fish and Game Commissioner, Albany; N. Y.

Mr. Austin Cary, Superintendent State Forests, Albany, N. Y.

Mr. G. G. Atwood, Chief Nursery Inspector, State Department Agriculture, Albany, N. Y.

Prof. J. W. Toumey, Yale Forest School, New Haven, Conn.

Mr. H. R. Bristol, Forester, D. \& H. R. R., Plattsburg, N. Y.

Hon. Geo. Aiken, Forest Commissioner, Woodstock, Vt.

Mr. John Foley, Assistant Forester, Penn. R. R., Philadelphia, Pa.

Prof. F. C. Stewart, State Agricultural Experiment Station, Geneva, N. Y.

Mr. S. N. Spring, Consulting Forester, New Haven, Conn.

Prof. C. C. Curtis, Prof. of Botany, Columbia Unniversity, N. Y.

Hon. R. P. Bass, Forest Commissioner, Peterboro, N. H.

Charrman.-Gentlemen, I assume we ought to get right at this matter so that we can get our work done and get away.

Some days ago Mr. Pettis, one of our foresters, called my atten- 



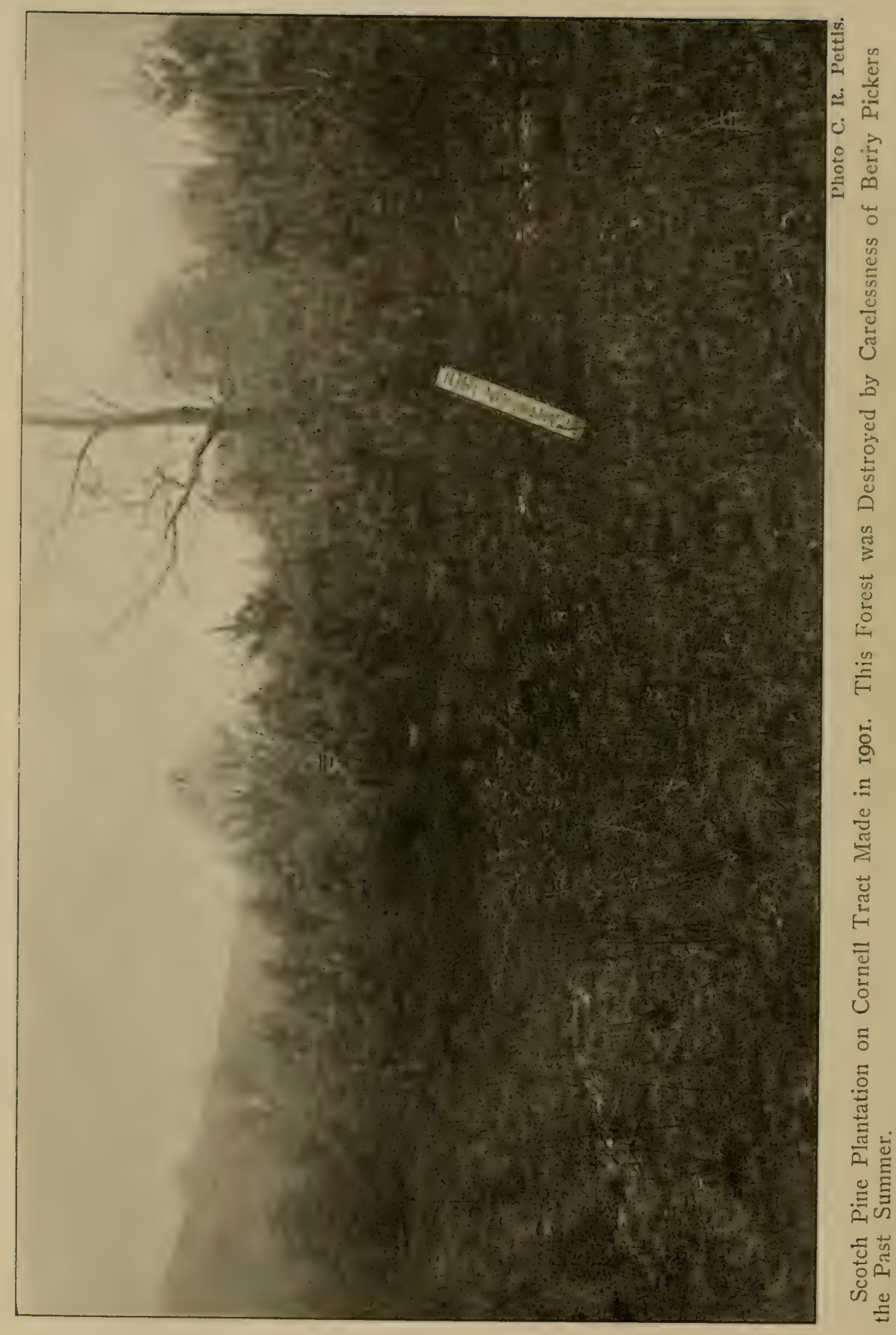


tion to the fact that it was evident that a disease, very dangerous to white pine and imported into this country, had appeared in ot: s!lipment of trees from a nursery in Germany, and he brought me some of the specimens that he found in the Lake Clear nursery. I was informed by him and Dr. Spaulding, who represented the U. S. Department of Agriculture, that it might be serious indeed. not only to us in the State of New York but in the adjoining states in the eastern part of the United States. I realized that unless the situation, to some extent at least, was promptly handled, serious results might follow.

We have been to great trouble and some expense in getting the public sentiment aroused along the line of having our people plant trees in the State of New York, other states have done the same; and if this matter was not handled diplomatically and promptly I could see how, in this State, we might be set back in this work many years, which would be very injurious to us further than the mere effect of the disease of the trees.

I am delighted to see that so many of you are here. I know nothing or little about it myself, from a technical or scientific standpoint, as I am not a scientific man; but calling you here by the few facts stated in my letter, and without saying anything further about it, I will ask Mr. Pettis to make a brief statement about it and then we will ask Dr. Metcalf to talk to us about the matter, and I hope that each person here will give us his idea upon any phase of it, as to how we shall treat it, how to eradicate it, as to the further importation of trees of this character, the relation of the State to the National Government, and how we can work in harmony. Perliaps we ought to discuss as well the question of the tariff upon trees, it appearing that Mr. Paine, in the House, believed there slould be a tariff and has put it back in his bill which was carried. All of these things we may want to discuss.

Mr. C. R. PETris.-About all I can say is simply to state how we discovered the disease. This spring we imported about 250,000 three-year old white pine transplants and about 800,000 two-year 
old white pine seedlings. None of the seedlings showed any signs of infection but a few of the transplants had already developed it. It was first found in the field by one of the men and he did not now what it was. I got into communication with him and secured some of the diseased trees which led me to believe they were effecterl with the German Pine Rust. Dr. Spaulding was at that time at Saranac Inn and he immediately took up the problem with pathologists in different parts of the country who confirmed our identifications. We found that it had also developed in some three-year old transplants in the Lake Clear Nursery. This is an explanation of the discovery of the disease. Dr. Spaulding was there and Dr. Netcalf soon came and they made investigations in other states.

Dr. Haven Metcalf, Pathologist, Bureau of Plant Industry, U. S. Department of Agriculture-- Perhaps in this matter I better say a word or two in regard to the disease itself and its nature.

The disease is a rust and up to the present time has been known exclusively in Europe. It lives a part of its life on one host and part of its life on another. This particular rust living part of its life on the white pine and the other part on various kinds or currants. It is an interesting fact that this disease has already appeared in this country and on this continent. One stage was discovered in 1906 by Prof. Stewart, of the Geneva Experiment Station, in this State and he promptly eradicated the disease and it has apparently been eradicated ever since. But it was never before found here on white pine. The disease in Europe is serious. I do not think that the seriousness can be over estimated. It is not so much as to what it may do in Europe as it is to the possibilities of what it might do here generally. We know that in the introcluction of cliseases of humankind they show that on coming to a new country a new lease of life, and in addition to the increaser vigor that might come to this parasite on the white pine, there is another species of pine that it might come in contact with in the west, and we do not know what it would do then. Pathologists for a number of years have been on the lookout for this disease. Now, as has already been said, it has been imported - it is here on 
German transplants. We know positively at the present time that ir is in New York, Vermont, Connecticut and Massachusetts, and we do not know where else, that is yet to be determined. So from that mere fact of distribution it is a serious question, which is really one of national importance, affecting not only the states where the disease may already be at present, but affecting all the states where white pine is grown. The disease I do not say is one that essentially kills nursery stock, but it also occurs on the adult tree.

Of course the first question that arises in our minds is what we are going to do about it and in that connection I might say that whatever we are going to do, or are not going to do, must be done now because if the thing is permitted to go another year it will be absolutely beyond the possibility of control of any sort; and in the sccond place I may say that the proposition of the control of this disease is purely a problem of pathology. When the disease is in its most obvious condition, it is very easy to detect, but in the stage which it is in at this time of year, it is not so easy; in other words, the entire question of eradication, or rather inspection, or whatever method is advocated, will have to be at least under the direction of expert pathologists.

Now, Dr. Spaulding and myself have known of this matter for cnly a short time, a couple of weeks, and in that time we have not had opportunity to look the entire situation over so far as we would wish; so far as we have looked the situation over, however, we believe that the disease can be stamped out at this stage by thorough inspection, with eradication of the disease in suspected plants. That necessarily involves a visit to every place where these imported trees have been planted; it means going over every planting; it means that the person who is doing the inspecting must go over every individual plant, and that is necessarily quite a task. There is also another difficulty that the disease which has occurrerl this spring may already have spread itself to currants, and currant bushes will have to be gone over, and that would have to be done in August; so you can see it is a very serious problem, and now is the time if it is ever going to be done. 
In conclusion I must say that the National Department of Agriculture stands ready to assist in every way and I want to say frankly that we have no desire whatever to "but in ;" if the situation can be handled by the pathological forces in the states themselves, it had better be handled in that way. But the thing is a national question as it affects every state throughout the white pine range, and so we naturally and necessarily feel a very decided interest in the situation.

Specimens of diseased pine and photographs were then passed to each member present and a discussion followed among those present as to the elimination of the disease.

Prof. F. C. Stewart, Botanist, Agricultural Experiment Station, Geneva, N. Y.- I might say that all I know about this matter is what is printed in our Technical Bulletin No. 2 (I think Mr. Pettis has distributed among you a copy of that bulletin), it is entitled "The Epidemic of the European Currant Rust." In the fall of I 906 we found that our currant plantation, at the Geneva Station, containing a large number of varieties and representing several species, was thoroughly infested with this disease. It appears as a rust underneath the surface of the leaves. We do not know how we got it. It is true we have been importing currants from Europe but the last importation we made was in 1904 and this outbreak occurred in the fall of 1906. Now, to the best of our knowledge, the disease cannot live from one year to the next on the currant; it is in the leaves only on the currant and when these leaves drop off the disease is gone, so far as the currant is concerned. It must come to the pine before it can come back to the currant again, and we were unable to determine how we got the disease. We inspected the pine trees in the vicinity and there were very few in the immediate vicinity; there were two young pine trees within twentyfive feet of the plantation of currants, but these were perfectly healthy and have remained healthy to-day;: we watched them carefully and they are still healthy and there were none of the pines 
that could have this disease close by. I immediately saw that the disease attacks only those pines which have their leaves in clusters of five. We were, of course, very much worried over the matter; we did not want the disease to get started at the Experiment Station; we did not wish to be the agent of introduction, and so we very promptly eradicated the disease in the whole plantation. That was in the fall of 1906 and we did not plant any more currants until a year ago this spring, that is, we missed one year. We have not seen any rust on our currants since and none has appeared on the pines, so far as we have been able to detect. I think there is. one very hopeful feature about this situation, and it is this, that although we have been importing from Europe for a considerable number of years and in considerable quantity, and this disease is common in Europe, especially in northwestern Germany, still the disease has not become established up to the present time. We feel pretty sure that our pathologists are alert and the disease is a conspicuous one and it is safe to say that it is not established in this country, notwithstanding the fact that we have been importing pines pretty freely, but I think we ought to take very radical measures to get rid of it, notwithstanding.

Mr. Raphael Zon, of the Forest Service, Washington, D. C., addressed the members on this subject and advocated imposing a duty on seedlings imported from Germany.

After further discussion, in which nearly every one present took part, the following named gentlemen were named as a committee to prepare a statement for approval, to be given to the press for publication: Dr. Haven Metcalf, Hon. R. A. Pearson, Hon. George Aiken, Mr. F. W. Rane, Mr. Alfred Gaskill, Hon. James S. Whipple.

The committee prepared and submitted for approval the following statement which was duly approved and given to the press for publication :

"Mr. Pettis, one of New York State's Foresters, and who has 
charge of tree nurseries and tree planting for New York State, discovered, about ten days ago, indications that what is known as the "European Currant Rust" or "Blister Rust," a disease which has affected white pine abroad, had attacked some of the young pine trees in the Lake Clear nursery of the State of New York. Specimens were immediately submitted to Dr. Spaulding, of the National Department of Agriculture, who was at the plantation at the time, and he pronounced it the "European Currant Rust" or “Blister Rust," confirming Mr. Pettis' notion about it.

"Commissioner Whipple immediately took the matter up and called a conference which was attended by the following named, well known, gentlemen from the National and State Departments. The conference was called at the Commissioner's New York city office, No. I Madison avenue, on June 28th:

Mr. W. O. Filley, Acting State Forester, New Haven, Conn.

Mr. A. F. Hawes, State Forester, Burlington, Vt.

Mr. Alfred Gaskill, State Forester, Trenton, N. J.

Mr. F. W. Rane, State Forester, Boston, Mass.

Mr. C. R. Pettis, State Forester, Albany, N. Y.

Dr. Perley Spaulding, Bureau of Plant Industry, Washington, D. C.

Dr. Haven Metcalf, Bureau of Plant Industry, Washington, D. C.

Mr. Raphael Zon, Forest Service, Washington, D. C.

Hon. R. A. Pearson, Commissioner of Agriculture, Albany, N. Y.

Hon. J. S. Whipple, Forest, Fish and Game Commissioner, Albany, N. Y.

Mr. Austin Cary, Superintendent State Forests, Albany, N. Y.

Mr. G. G. Atwood, Chief Nursery Inspector, State Department Agriculture, Albany, N. Y.

Prof. J. W. Toumey, Yale Forest School, New Haven, Conn.

Mr. H. R. Bristol, Forester, D. \& H. R. R., Plattsburg, N. Y.

Hon. Geo. Aiken, Forest Commissioner, Woodstock, Vt.

Mr. John Foley, Assistant Forester, Penn. R. R., Philadelphia, Pa.

Prof. F. C. Stewart, State Agricultural Experiment Station, Geneva, N. Y. 
Mr. S. N. Spring, Consulting Forester, New Haven, Conn.

Prof. C. C. Curtis, Prof. of Botany, Columbia University, N. Y. Hon. R. P. Bass, Forest Commissioner, Peterboro, N. H.

"The subject for which the conference was called was thoroughly discussed, and it is believed that no serious damage will occur, especially in view of the prompt action taken by all of the states represented in immediately proceeding to cradicate the danger caused by the appearance of the disease in the few places it has been found.

"Several of the northeastern states have imported large quantities of small white pine trees for reforesting land, and in some of the shipments the disease has been found. The affected trees, so far as we know, have come from a single nursery, in Germany, and it is well known where the trees have been planted, and for that reason it will be comparatively easy to take care of the trouble if promptly attended to. Representatives of the Bureau of Plant Industry of the United States Department of Agriculture and of the New York State Experiment Station have examined the diseased plants and agree that a complete eradication may be made now.

"The European Current Rust is a fungus disease which lives alternately on the white pine and the currant bush. It is most serious on small trees. The disease has not been reported in this country on white pine until this year; however, it was found on currant bushes at the Geneva, N. Y. Experiment Station in I905, but Prof. F. C. Stewart, of that station, took every precaution and eradicated the disease by destroying the infected currant bushes.

"The representatives of the conference believe that there is no reason whatever for alarm among those who have planted seedling trees and those who desire to do so. All those having planted will be asked by the Department to make a careful inspection of the trees planted and such trees as are found infected will have to be clestroyed. Agents of the New York Department of Agriculture who are making nursery and horticultural inspections in all parts of the State will be instructed to watch closely for the first appear- 
ance of suspicious indications, and where such departments exist in other states they will co-operate in the same way, as will also the National Department of Agriculture. In this way the danger will be entirely eliminated. It is a disease of trees that cannot be discovered until the disease has developed for a year, and for that reason any inspection at the docks on receipt of trees, unless it is fully developed, could not be effectual in the discovery of the trouble on receipt of trees on this side.

"Commissioner Whipple believes that the people as well as the Departments are to be congratulated that the disease has been quickly discovered and such prompt steps taken to wipe it out."

A letter was received from Hon. Robert S. Conklin, Commissioner of Forestry of Pennsylvania, saying it would be impossible for him to attend the conference but he "would like to be advised, however, of the action taken at the meeting and will be glad to endorse that action so far as this state is concerned."

Mr. F. W. Besley, State Forester, Baltimore, Maryland, wrote: "I agree with you that the question for discussion is an extremely important one and much will depend upon the prompt action that would be suggested by such a conference. I want to express my interest and desire to co-operate in a matter of this kind which has such a wide application. If I am unable to be present, as it now appears likely, please convey to the conference my high appreciation of the stand which you have taken and the assurance of my hearty co-operation in dealing with the threatened injury to white pine."

Prof. E. J. Zavitz, Department of Forestry, Guelph, Ontario, wrote: "I realize the seriousness of this situation and if it is thought advisable we shall cease importing white pine. I have been considering, during the last year, the advisability of growing all our own planting material from the seed, realizing the danger of importing disease. I shall be glad to co-operate in any way with the efforts of your conference."

Immediately following the conference in New York city a second conference was held in Albany at the office of the Commissionr of Agriculture to devise means to handle this disease in this State. 



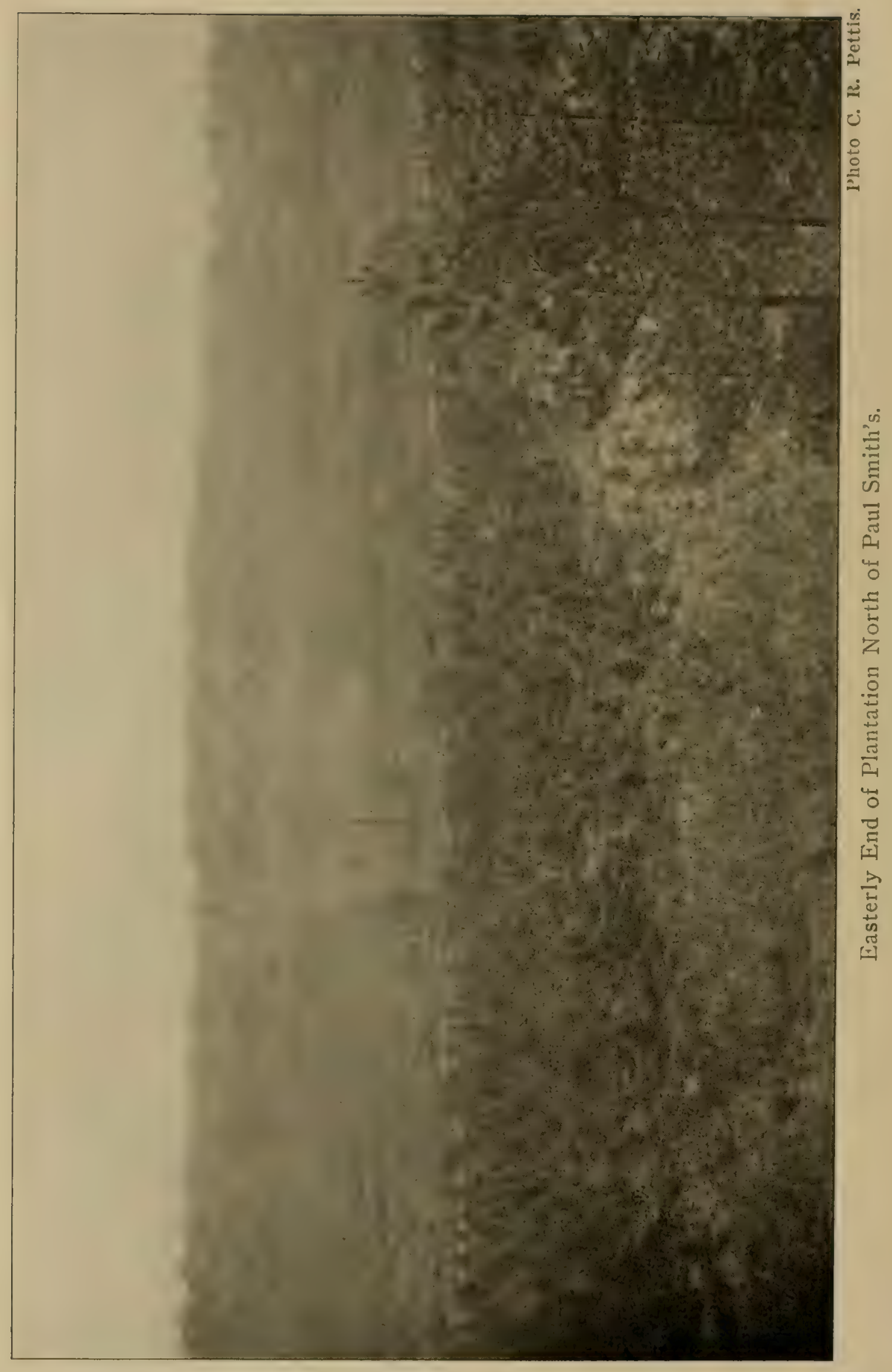


There were present: Hon. R. A. Pearson, Commissioner of Agriculture; Mr. George G. Atwood, Chief Nursery Inspector, Department of Agriculture; Prof. F. C. Stewart, Botanist at Agricultural Experiment Station, Geneva; Mrr. Austin Cary, Superintendent State Forests, and C. R. Pettis, State Forester. The following plan of work was adopted:

"I. Procure as complete as list as possible of every place to which Heins' white pine stock has gone during the past two years. It is our desire to extend this list to include all other stock imported from Germany and France.

"2. Inspect all such premises and destroy all Ribes plants, wild and cultivated, within roo yards from such trees, and even a further distance where practicable. The Ribes plants should be pulled up or cut off in such a manner as to prevent sprouting. For example, the skunk currant should be pulled up because it spreads from underground stems, while gooseberries and cultivated currants, difficult to pull, may be cut off below ground. Burn all such plants found as explained under No. 4 .

" 3 . Keep close tab on cultivated currants and gooseberries in all districts of the State where suspicious pines are located, and after July $I_{5}$ keep closer watch than heretofore on currants and gooseberries throughout the State.

"4. Destroy by burning all infected or suspicious pine or Ribes plants. This is especially important in 1909 for Ribes may be expected to show signs of the disease if at all after July I5.

"When the plants are to be burned it should be done where they are found or at.a place to which they are carried in bags made of closely woven heavy cloth such as canvas or factory, and all such bags should be thoroughly boiled or otherwise sterilized at the conclusion of each job.

"5. Suspicious pine plantings to be thoroughly inspecterl during the last two weeks in May and the first week in June (between May Io and June Io probably safe). This is very important in IgIO and should be repeated in I9II, the thoroughness in that year depending largely on 1910 findings." 
An examination of our shipping records indicated that German white pine seedlings had been sent to forty-six different applicants and that transplants were distributed to thirty-eight parties. A division of territory was arranged with the Department of Agriculture and the above plan was faithfully carried out and the work completed by August I5th. We wish to acknowledge the generous, efficient assistance given us by that Department and without their aid the work could not have been done early enough to be sure of satisfactory results.

In order that the disease may be combatted intelligently it is necessary to understand its life history. As already stated the disease is a rust and like other rusts it passes its life on two distinct kinds of plants. In this case the two plants are the white pines (here used to include all pines having five needles in a sheath and includes our native white pine, the sugar pine of the western United States, the European stone pine and a few others of lesser economic importance) and a group of plant called Ribes, which includes both wild and cultivated currants and gooseberry bushes. This disease is propagated by means of spores and in order for the disease to spread both pine and currant or gooseberry bushes must be located near enough together that the spores may be carried by the wind from one to the other. The disease is of but little importance as far as currants or gooseberries are concerned but to the pines it is most serious.

"The white pine blister rust* is particularly noticeable in the spring, from the middle of April to the middle of May. $t$ It then covers the trunk of young plants of four or five years and over, as well as the trunk and branches of older trees, with bright yellow blisters (Aecidia). From these blisters or bags blows a dark yellow

*A translation from circular No. 5 of the German Imperial Biological Institute for Agriculture and Forestry written by Prof. Dr. Carl Freiherr von Tubeuf and translated by A. J. T. Von Lear, published by the Department of Agriculture, Albany, I909.

$\dagger$ Prof. Stewart thinks that it is very doubtful if the disease appears as early in April in this country and would expect to find it the last two weeks of May. 
powder, consisting of the reproductive cells, or so-called spores, of the fungus, which are carried great distances by the wind. These spores can not develop unless they fall on the leaves of currant or gooseberry bushes, in other words on plants belonging to the genus Ribes. On these leaves they germinate, however, especially on Ribes nignum, aurcum, and sanguincum, but also on other species. The germ tubes enter the leaf tissue and felt into a mat of countless threads (Mycelium). After a few weeks, about the beginning of June, these form on the underside of the leaves of currant and gooseberry bushes bright yellow deposits of new reproductive cells, called Uredospores, which spread the disease from leaf to leaf of the Ribes bushes. On all the leaves on which these cells happen to fall, similar yellow deposits are formed in a short time. This increase and distribution lasts the entire season, so long as the young leaves are formed. In the summer, however, still other.reproductive cells (Teleutospores) are deposited on the underside of the infected leaves, which appear in the shape of yellow brown strings or sausages of the thickness of a hair. On the surface of these strings, tiny cells are deposited, so-called sporidia, which germinate only on the bark of young shoots of the white pine, but not on currant or gooseberry bushes.

"The relation between the white pine blister and the Ribes fungus which bears the name of Cronartium ribicolum, has been established by artificial infection, so that it is certain that the first (Periderminm strobi) is but a stage in the development of the second (Cronartium ribicolum).

"The last named sporidia, which come from the Ribes fungus, are produced and carried by the wind at the very season that the young white pine shoots have begun to develop and are in a condition to be readily infected. When the small sporidia germinate their germ tubes penetrate the tender bark of the white pine and there mate again (Mycelium). This tissue lives for many years in the branches and occasions considerable swelling of the shoots, by which the disease may be detected, also in the fall and in the winter when there are no yellow deposits on the bark. 
"On the surface of the infected branches, probably not until several years after the infection, spore blisters are formed, such as are described at the beginning of the article. For a number of years these reappear every spring on the same swelling. (Their appearance is preceded by the formation of very small, almost dot-like heaps of spores, so-called spermogonia, with sweet tasting, sticky spores, so-called spermatia, about which nothing further is known.)

"At the end of the above mentioned processes, the fungus passes the winter on the bark of the white pine, is carried in May to the leaves of the Ribes plants, spreads from Ribes to Ribes, and returns the same summer to the white pine. Only in case of very thorough infection it causes the leaves of the Ribes plants to dry up before their time without, however, doing very serious injury to the plants. On the white pines it produces swellings upon which the yellow blisters are formed. The swollen parts of the bark afterward crack and split and die off at an early date. In consequence hereof the parts of the young plants that are situated above the infected bark, and the branches and upper parts of trees, dry up also. The thinner the bark the sooner it is eaten through and destroyed by the fungus.

"The damage caused by the fungus consists in the loss of young stock in nurseries, gardens and neivly planted forests, the drying up of branches and general disfigurement of older trees, and finally the dying of whole trees in parks and forests.

"The epidemic character of the disease has been verified more than once. Instances are known in which a very large percentage of the plants in extensive plantings have been destroyed by the pine blister, causing a large financial and still larger forest culture loss. The disease has led to the cutting down of many trees in parks, it has killed a great many saplings in forests, it renders entire beds of infected plants in nurseries worthless for purposes of sale and has even induced many practical nurserymen to give up the growing of white pine altogether."

This disease has been the subject of much investigation and writing abroad, but Klebahn is the most authoritative writer and Die 



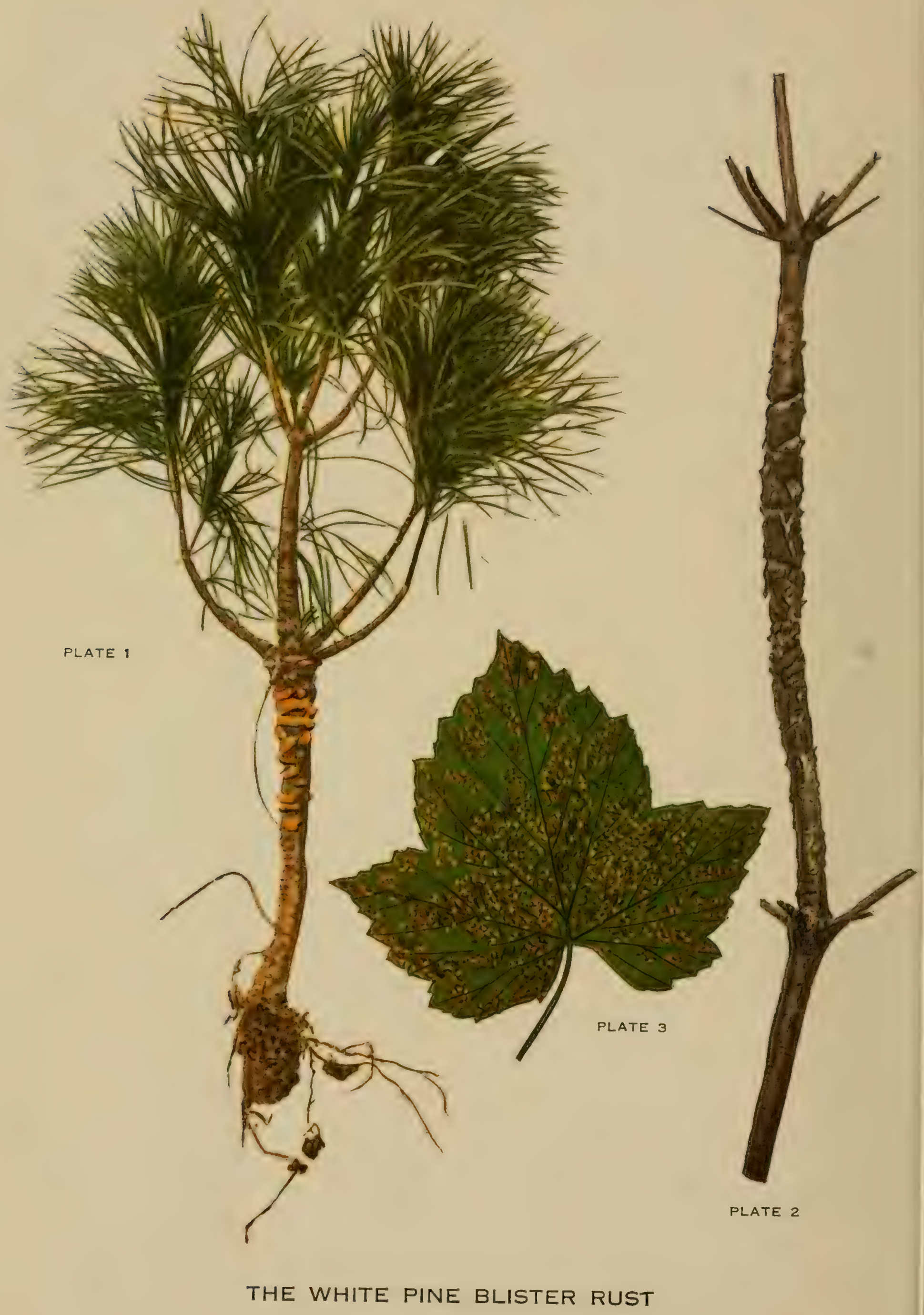


Wirtucchselnden Rostpilze his best work. Horticultural Bulletin No. 2 "Emergency Bulletin on the Blister Rust of Pine and the European Currant Rust" prepared by Mr. George G. Atwood, has been issued by the State Department of Agriculture, Albany. Circular No. 38 of the Bureau of Plant Industry, Washington, D. C:, "The European Currant Rust on White Pine in America," by Dr. Perley Spaulding, has also been published since the disease was discovered in this country.

In Europe, according to Prof. Sommerville, the disease is so much on the increase that the outlook in that country for our white pine and other five needed American pines is almost hopeless. There are estates in England where hardly a living young white pine is left. In Denmark and in some places in Russia, as near Moscow, for instance, the raising of white pine had to be entirely given up on account of this rust. The same is true of Holland and portions of Germany. Other European countries are affected.

The seriousness of the disease must not be underestimated. The value of white pine from a forestry standpoint is too great for us to allow its future to be threatened in any way. It would be far better to delay a part of our reforesting until American nurseries can be established which will produce the necessary planting stock.

The people of this State have no cause for alarm because every known plantation made with German white pine in this State has been carefully examined, the Ribes destroyed and the inspection will be continued the coming spring. We can further say that every effort will be made by us to prevent importations of pine. The disease is well under control and our only trouble will be to prevent nurserymen and private parties from importing.

The accompanying colored plate shows the appearance of the discase and an explanation follows:

Plate I. A live, young white pine plant, showing swelling of the trunk and of the branches at the whorl, and on these swollen parts the yellow spore bags (Aecidia) of the Pcridcrmium Strobi.

Plate 2. Branch of the white pine, showing the swelling caused 
by the blister rust. The entire swollen part and the branches starting from it are already dead. The bark is torn. The Aecidia of last year have dropped off.

Plate 3. Currant leaf with Cronartium ribicolum on the under side. The bright yellow deposits are the Uredospores, which spread from Ribcs to Ribcs; the brownish strings are the Teleutosspores, whose Sporidia again transmit the disease to the white pine and there produce the Pcridermium Strobi.

\section{Reforesting State Lands.}

On account of the great demand for trees by our land owners this work was practically abandoned for the present year.

At the Paul Smith's Plantations, 7,000 Scotch pine transplants were set, in fail places, by the man watching the plantation during the spring.

A plantation of 60,000 trees was made on the land acquired for the Delaware Fish Hatchery, near Margaretville, to protect the water suppply. This is the second plantation on State land in the Catskills.

At Chubb Hill (near Lake Placid) 30,000 trees were planted and the area of this plantation increased twenty-five acres.

During the summer our plantations have been surveyed and carefully mapped for future reference.

All our plantations are making a very satisfactory growth.

\section{Seed Spot.}

The seed spot is, next to broadcast seed sowing, the simplest method of artificial reforesting. It consists essentially in preparing little spots, usually about one foot in diameter, regularly over the field that is to be reforested. This plan of artificial reforesting does not require any nursery for propagating the trees because the seed is planted where it is desired to grow the future tree. In 1904 about ten acres of seed spots were made at Chubb Hill, near Lake Placid. The work was done in the fall with white pine seed gathered the same season. In 1905 forty-two acres were made in 



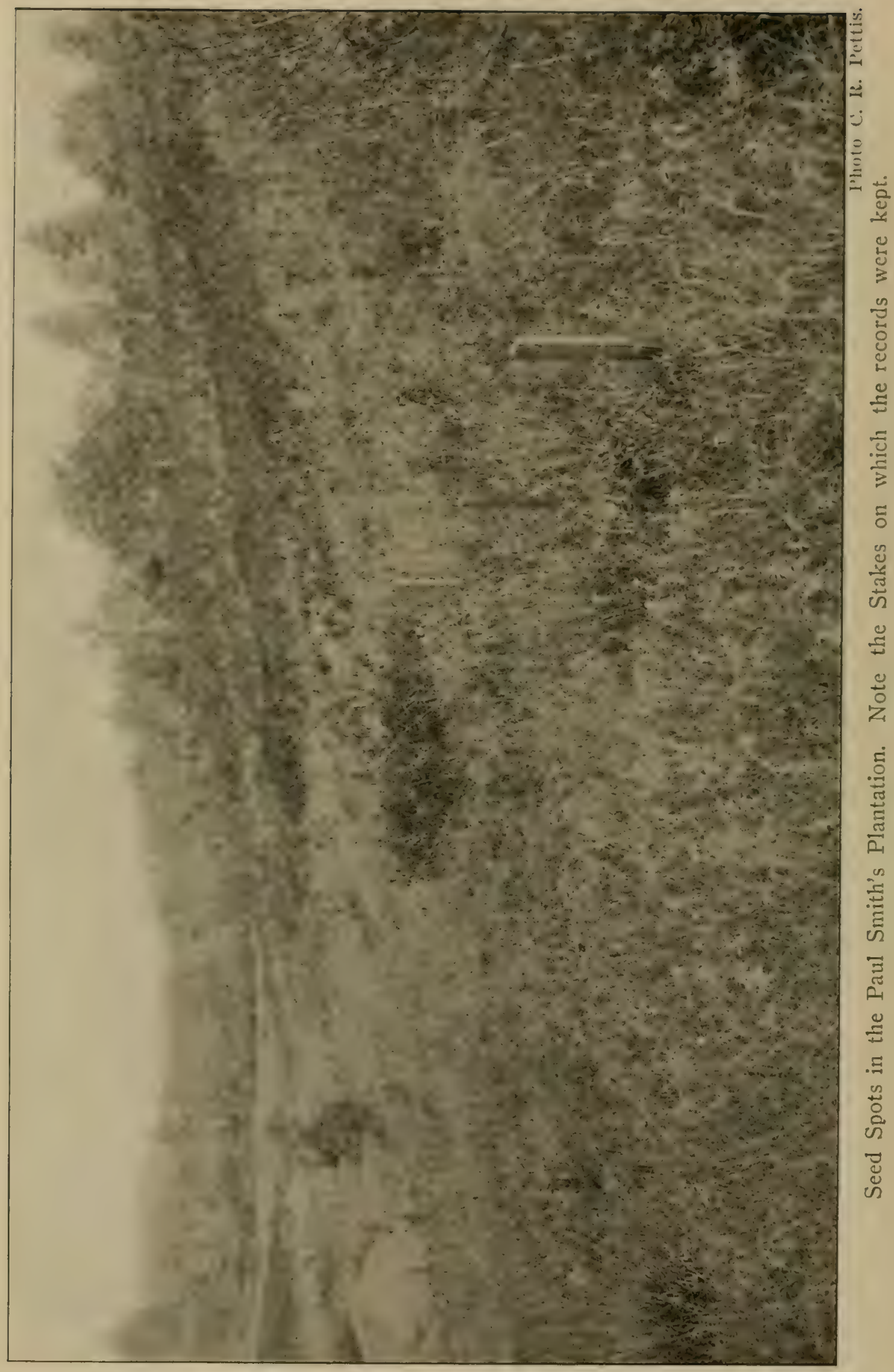





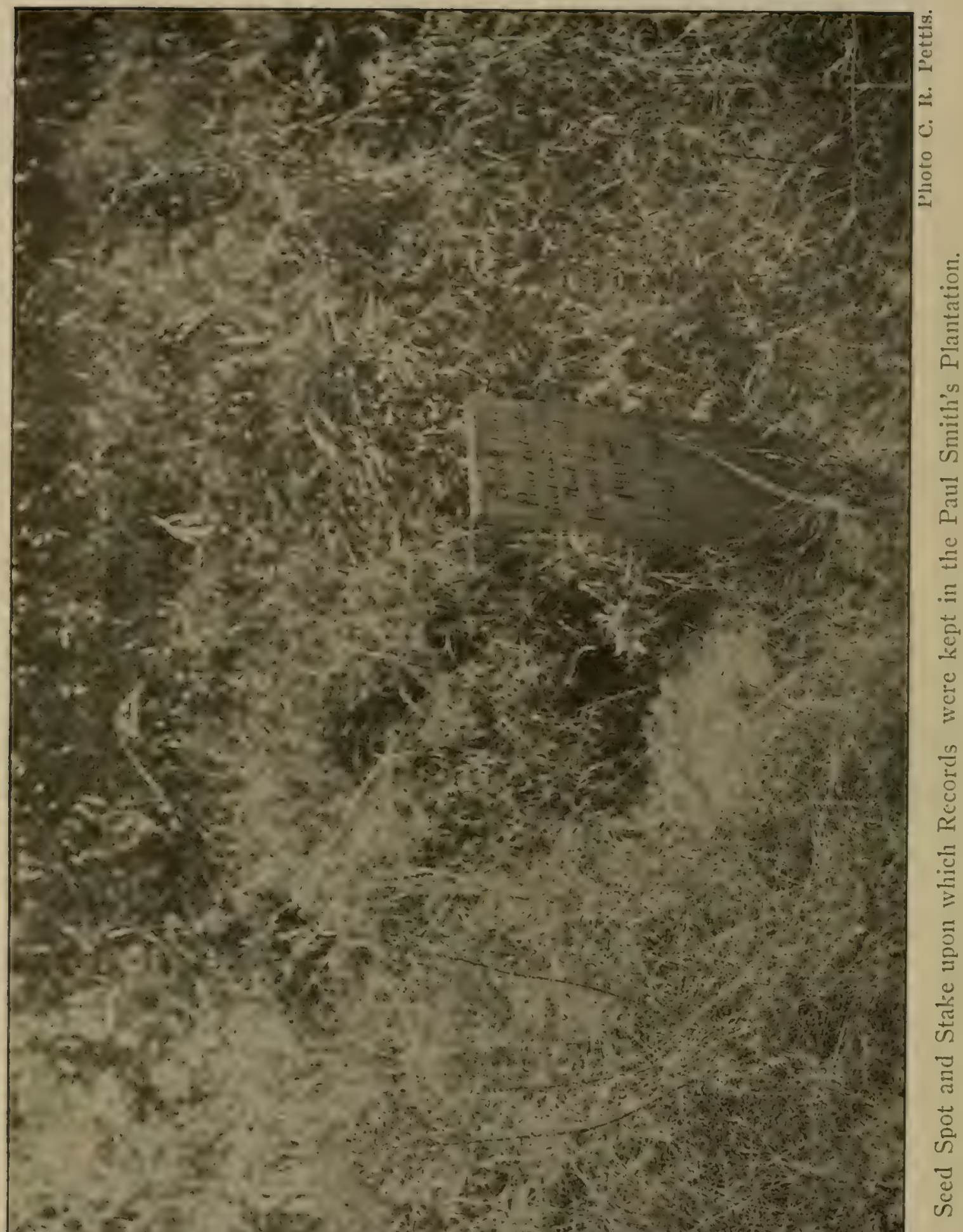





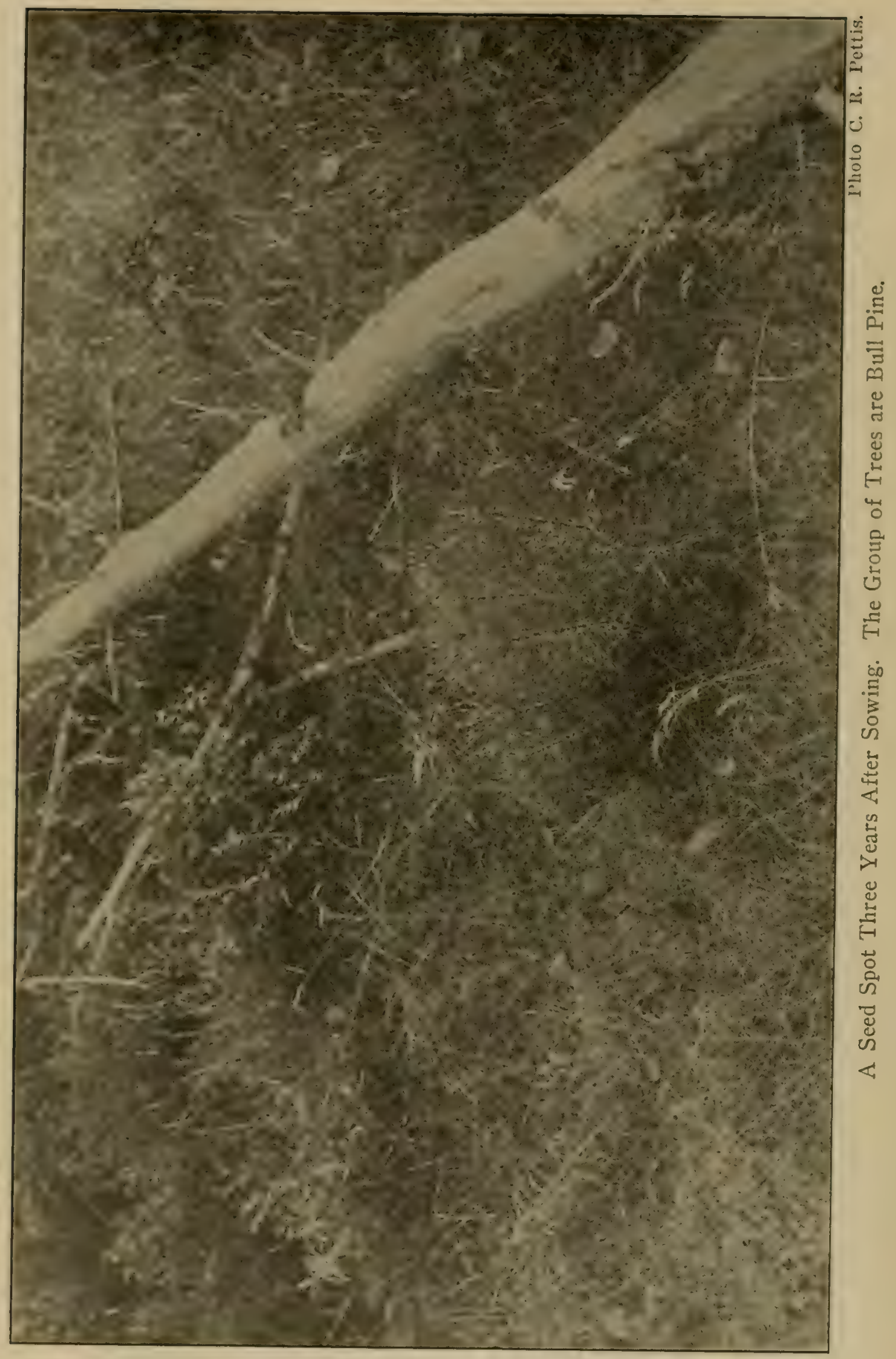




our plantation north of Paul Smiths and at this time white and Scotch pine were used. In 1906 about eleven acres more of seed spot was made in this same plantation when Norway, white, native red and Douglas spruce, also some balsam and Norway pine seed was used. The seed spots were further increased by about thirty acres in Igo7 when several kinds of pine, spruce and other coniferous seeds were used.

Several kinds of seed spots have been made, viz.: large spots, small spots, hole hillocks, and unprepared ground. The large and small spots were made by loosening up the soil and preparing a small clean seed bed, in the former case from $\mathrm{I}_{2}$ to $\mathrm{I}_{5}$ inches in diameter, while in the latter about 6 inches in diameter. The hole hillocks were made by overturning a large thick sod and sowing the seed on the overturned soil. In the case of unprepared soil there were two methods, one of them being to sow sceds broadcast on the ground (which was covered with a light grass sod), the other plan was to cover the seeds, sown on the unprepared ground, with a handful, or more, of dirt which was carried in a pail for the purpose.

The cost of this work naturally varies with the kind of spots. In all cases these spots have been made under favorable circumstances, as regards ground, cover, thus contributing to low costs. A careful examination of the expenditures made and acreages planted indicates that \$IO per acre is about the average cost.

In order to secure information upon which to base future work careful counts were made this summer of $2,23 \mathrm{I}$ seed spots made in 1906 and 1907 of various species. The accompanying illustrations give a much better idea of the condition of the ground cover than can be done by description. It also indicates the stakes, set at the end of each row of spots, upon which were inscribed proper legends denoting the species used, kind of spots, date of planting, and treatment of the seeds. All of the seeds were coated with red lead before planting.

The accompanying tabulation shows the results of our counting. The results show that on the average 35 per cent of the spots 


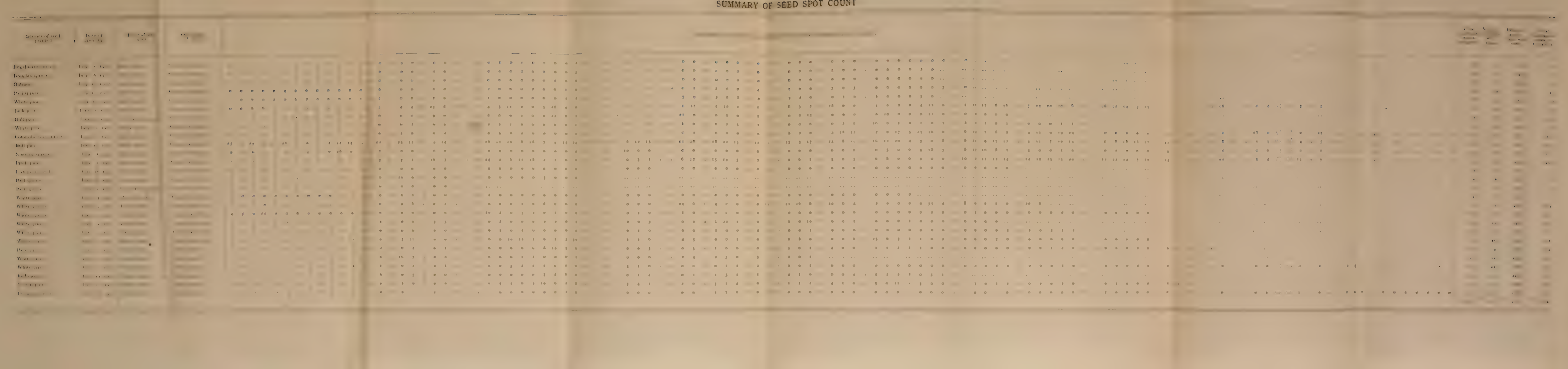



now have trees. The spruces, larch and balsam are not desirable species for the work. About 40 per cent of the white pine spots have trees. Bull pine, in one case, shows 94 per cent of the spots growing trees with an average of over ten trees in a spot. This is by far the best showing and is the only one that seems to indicate the desirability of seed spot planting.

\section{Experimental Work.}

In order to test the desirability of planting young stock the following aged species will be set in sample plots the coming spring:

Type I. On sandy soil with no shade:

White pine 2-year seedlings, I + I transplants, $2+1$ transplants.

Scotch pine 2-year seedlings, I + I transplants, 2 + I transplants.

Red pine 2-year seedlings, I + I transplants, $2+$ I transplants.

Bull pine 2-year seedlings, I + I transplants, $2+$ I transplants.

Type II. On fertile loam, little or no shade:

White pine 2-year seedlings, I + I transplants, $2+$ I transplants.

Scotch pine 2-year seedlings, I + I transplants, $2+$ I transplants.

Type III. Under-planting of mature hardwoods:

Heavy shade (density .9):

Norway spruce $2+$ I transplants, $2+2$ transplants.

Moderate shade (density . 5 ):

Norway spruce $2+\mathrm{I}$ transplants, $2+2$ transplants.

Type IV. After clear cutting:

Norway spruce $2+$ I transplants, $2+2$ transplants.

Type V. Under-planting second growth poplar, sandy soil:

White pine 2-year seedlings, I I transplants, $2+$ I transplants. 
Scotch pine 2-year seedlings, I + I transplants, $2+$ I transplants.

Red pine 2-year scedlings, I I transplants, $2+$ I transplants.

Norway spruce 2-year seedlings, I + I transplants, $2+$ I transplants.

There are, in connection with the management of our nurseries, several problems which have been referred to in previous reports and work upon them will be continued.

Very respectfully yours,

C. R. PETTIS,

State Forester.

Albany, N. Y., December 2I, Igog. 



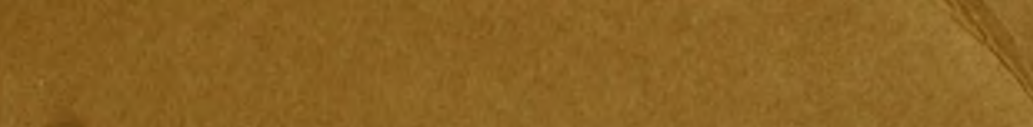

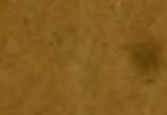

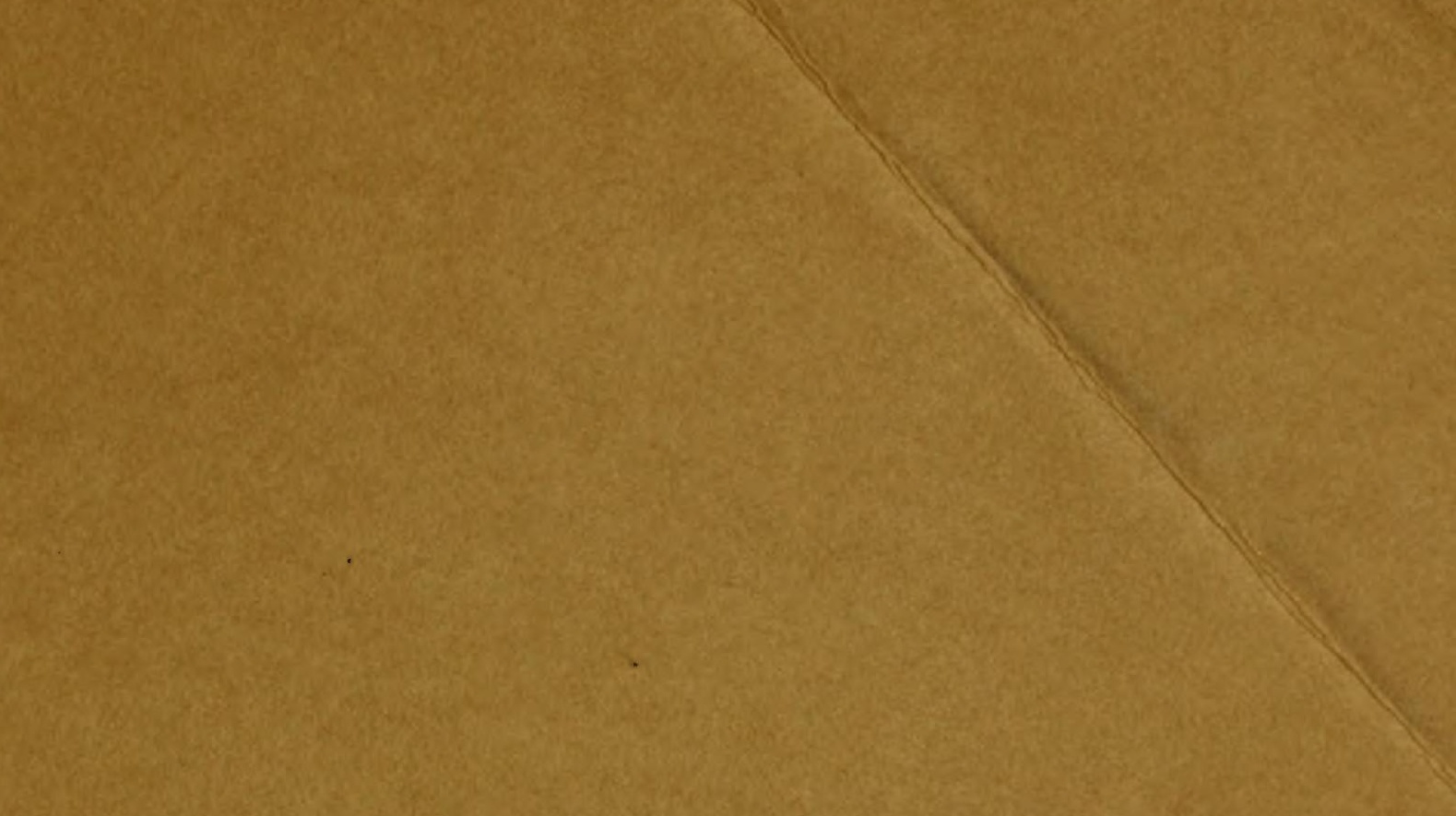

$\log ^{2} \rightarrow \log ^{2}$

Q284 nowis

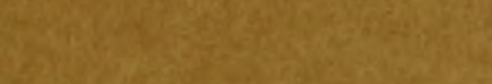

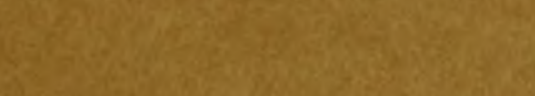

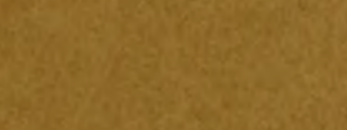

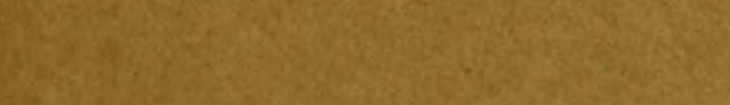

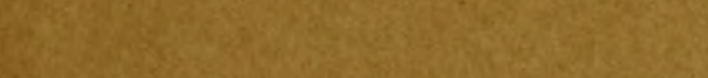

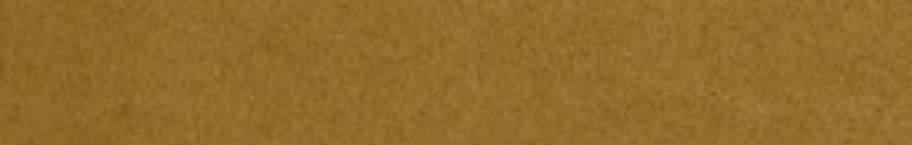

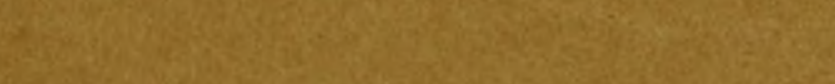

Wet

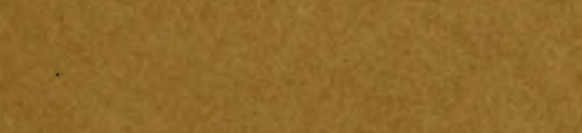

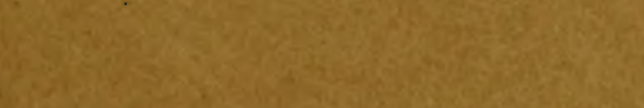

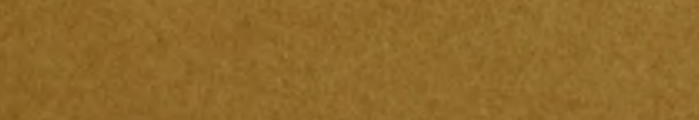

Ge

Whes

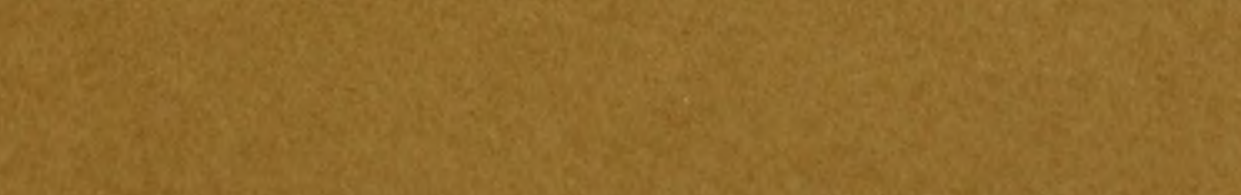

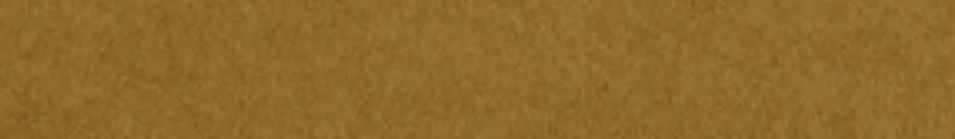

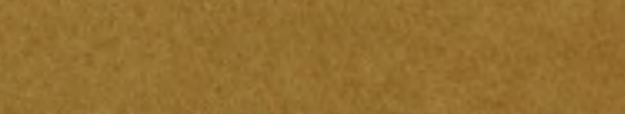

5.

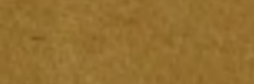

49.

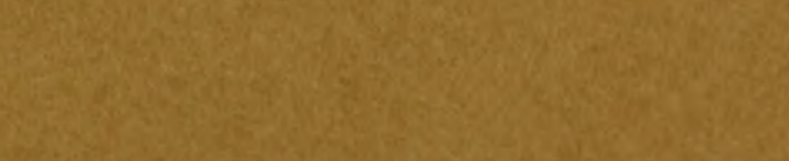

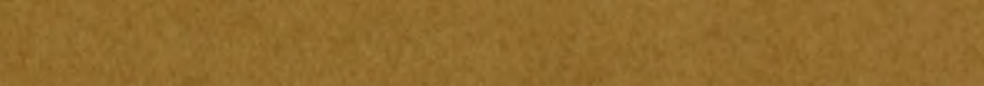

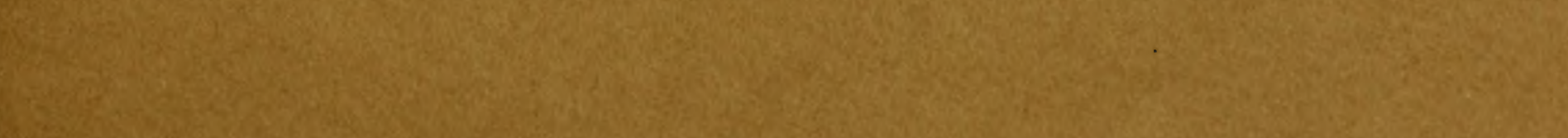

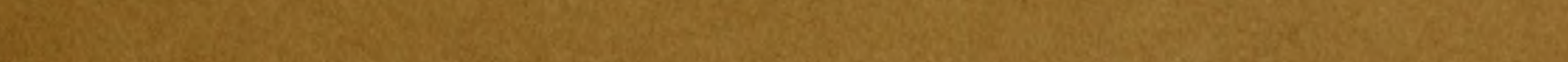

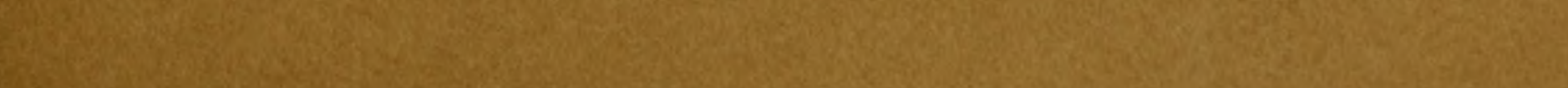

26. H. 



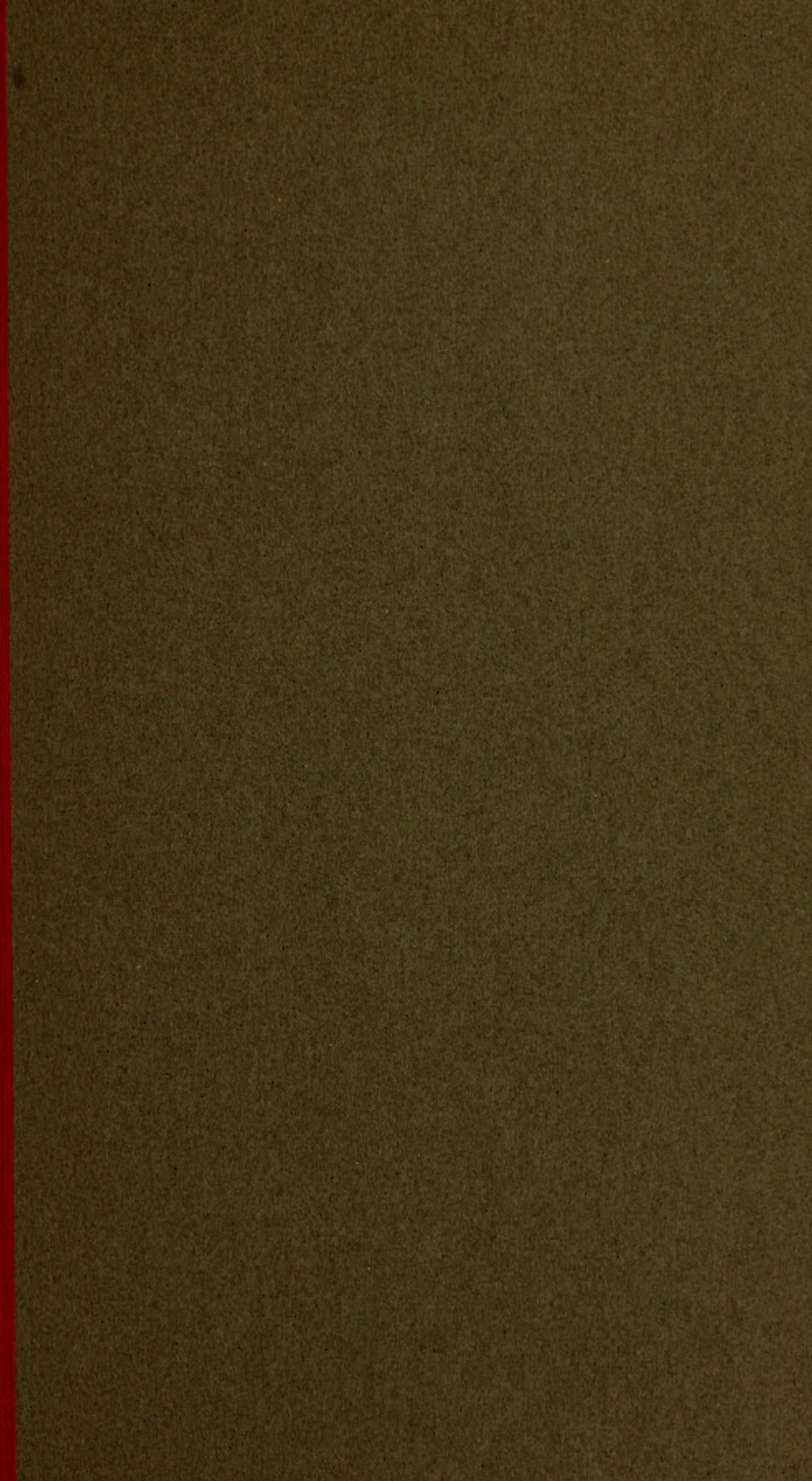


LIBRARY OF CONGRESS

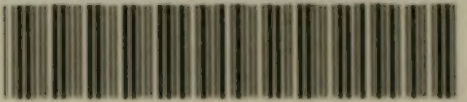

00008970798 